\title{
Hello, Goodbye: When do States Withdraw from International Organizations?
}

\author{
Inken von Borzyskowski ${ }^{1}$ and Felicity Vabulas ${ }^{2}$
}

Review of International Organizations (2019)

\begin{abstract}
$^{3,4}$
Under what conditions do states withdraw from intergovernmental organizations (IGOs)? Recent events such as Brexit, the US withdrawal from UNESCO, and US threats to withdraw from NAFTA, NATO, and the World Trade Organization have triggered widespread concern because they appear to signify a backlash against international organizations. Some observers attribute this recent surge to increasing nationalism. But does this explanation hold up as a more general explanation for IGO withdrawals across time and space? Despite many studies of why states join IGOs, we know surprisingly little about when and why states exit IGOs. We use research on IGO accession to derive potential explanations for IGO withdrawal related to domestic politics, IGO characteristics, and geo-politics. We quantitatively test these potential explanations for withdrawal using an original dataset of more than 493 IGOs since 1945, documenting more than 200 cases of withdrawal. We find that nationalism is not the key driver of IGO withdrawals in the past. Instead, we show that geo-political factors - such as preference divergence, contagion, and the IGO's democratic density - are the main factors linked to IGO withdrawals. These findings have important implications for research on the vitality of international organizations, compliance, and the liberal world order.
\end{abstract}

Keywords: international organizations, withdrawal, international institutions, exit, nationalism, liberal order, compliance, international law

${ }^{1}$ Assistant Professor, Florida State University. Email: i.Borzyskowski@fsu.edu

${ }^{2}$ Assistant Professor, Pepperdine University. Email: felicity.vabulas@pepperdine.edu

${ }^{3}$ We thank Xinyuan Dai, Cristobal Rovira Kaltwasser, Christian Rau, Henning Schmidtke, Duncan Snidal, Alexander Thompson, Svanhildur Thorvaldsdottir, Alexander Tokhi, Stefanie Walter, as well as conference participants at MPSA, PEIO, the Global Governance group at the Wissenschaftszentrum Berlin (WZB), and three anonymous reviewers for useful comments and suggestions on earlier drafts. We also thank Richard Saunders for excellent research assistance.

${ }^{4}$ The online appendix is available on the Review of International Organizations' webpage. 


\section{Introduction}

Under what conditions do states withdraw from intergovernmental organizations (IGOs)? Due to scholars' focus on joining, growing, and enhancing IGOs, ${ }^{5}$ research to date has largely ignored the causes of voluntary exit ${ }^{6}$ from IGOs. Recent events have brought heightened attention to this question. For example, in President Trump's first two years in office, the United States withdrew from UNESCO ${ }^{7}$ and the International Coffee Organization ${ }^{8}$ as well as threatened to pull out of NATO, NAFTA, and the World Trade Organization. ${ }^{9}$ In Europe, the United Kingdom's withdrawal from the European Union - which has been termed "Brexit" stands to fracture the continent. In the southern hemisphere, Burundi has withdrawn from the International Criminal Court, trying to escape an ongoing investigation and potentially foreshadowing more human rights violations. These withdrawals and threats of exit are significant because they seem to stand in contrast to well recognized patterns of increasing membership in IGOs at least since World War II. ${ }^{10}$ What is driving these retreats from international institutions?

Many observers cite nationalism or populism as the cause of recent IGO withdrawals. Snyder (2019) summarizes the seeming consensus: "The populist onslaught has, understandably,

\footnotetext{
5 Abbott and Snidal 1998.

${ }^{6}$ Hirschman 1970.

${ }^{7}$ See https://www.pbs.org/newshour/politics/u-s-and-israel-officially-withdraw-from-unesco. Accessed March 12, 2019.

${ }^{8}$ See https://dailycoffeenews.com/2018/04/03/the-united-states-is-withdrawing-from-theinternational-coffee-agreement/. Accessed March 12, 2019.

${ }^{9}$ If one looks beyond withdrawals from formal IGOs, the pattern of recent US withdrawals looks even starker, including withdrawals from treaties (that are not IGOs because they do not include Secretariats), informal agreements, and emanations such as the Joint Comprehensive Plan of Action (Iran Nuclear Deal), Paris Climate Accord, UN Human Rights Council, and the Transpacific Partnership.

${ }^{10}$ Pevehouse, Nordstrom, and Warnke 2004.
} 
prompted many liberals to conclude that nationalism itself is a threat to the U.S.-led liberal order." 11 Another account argues that "deepening fissures [have emerged] in the long-running project of globalization. Over several decades, that project has produced significant shifts in public opinion around the world, including ascendant national pride, antipathy to migrants, and growing skepticism about the legitimacy and effectiveness of international institutions." ${ }^{12}$ In short, many have argued a similar refrain that "the era of neoliberalism is over. The era of neonationalism has just begun." 13

While nationalism may have driven some recent IGO withdrawals, we question whether nationalism can provide a broader explanation of withdrawals over the long-term. We are skeptical of a persistent nationalism-withdrawal link because nationalism explanations usually do not take into account that states have been withdrawing from IGOs for decades and because the causes underlying nationalism may provide a better explanation for IGO withdrawals. Moreover, while there may indeed be rising nationalism among the populace, public opinion with regard to foreign policy does not always translate directly into politicians' vote shares or actions. ${ }^{14}$ In other words, while an increasing number of populist-nationalist voters may desire a retreat from international institutions, as outlined in the top left quadrant of the $2 \times 2$ table in the introduction to this Special Issue, we may not see a rise in actual IGO withdrawals due to alternative options, the difficulty of actually withdrawing, or the lower salience of international issues in voting decisions. We also question whether IGO withdrawals are mostly due to their high costs or inefficiency, as politicians tend to argue. Politicians frequently state reasons for IGO withdrawals

\footnotetext{
${ }^{11}$ Snyder 2019: 54.

12 Foa 2016.

${ }^{13}$ Blyth 2017. See also Fukuyama (2016) where he argues a "new populist-nationalist internationale has appeared."

${ }^{14}$ Holsti 1992.
} 
in public - such as the IGO being ineffective - but we are skeptical of taking a politician's rhetoric as fact because publicly stated reasons and actual reasons may differ.

Instead of only looking at recent withdrawals and taking politicians' publicly stated reasons at face value, we invert the robust literature on states joining IGOs to derive potential explanations for IGO withdrawal. In doing so, we follow the logic of scholars who have studied treaty termination by thinking first about why states decided to join. ${ }^{15}$ Using the IGO accession literature as our point of departure, we group our explanations into arguments focused on domestic politics, IGO characteristics, and geo-politics. Since many mainstream arguments which focus on populism and nationalism emphasize the role of domestic politics as a driver of state behavior vis-à-vis IGOs, we begin with this perspective. We then contrast this perspective with logics that focus on the characteristics of IGOs themselves and geo-politics as alternative logics that might explain IGO withdrawal.

We use our original data to systematically examine IGO withdrawals from 1945 to 2014. We find that nationalism -- measured by who is in office and the public support that politicians received during recent elections -- has not been a key factor in driving withdrawals in the past (1945-2014). These results focus on states' actual actions (IGO withdrawals) and are a nuanced contrast to findings linking rising nationalism to increased negative public opinion toward international institutions (such as Bearce and Scott in this Special Issue).

Instead of nationalism driving IGO withdrawals, we find that geo-political factors are important drivers for IGO withdrawals in two ways. First, we find that a significant change in a state's preferences vis-à-vis other IGO members increases the likelihood that the state withdraws from an IGO. When a state's preferences diverge from the average preferences of other IGO

${ }^{15}$ Leeds and Savun 2007. 
members, remaining a member may not be beneficial and could also be costly if collective policy decisions run counter to the state's interests. We also find a contagion effect behind withdrawals: when a lead state in the IGO withdraws - measured in various ways - other states are far more likely to follow suit, as they might be worried about a leadership vacuum that can exacerbate internal collective action challenges. Last, we find an IGO characteristic to be important for withdrawals. Countries are less likely to leave densely democratic IGOs perhaps because they have a more uniform group of member state preferences, may help ensure stronger IGO commitments, and are known for providing democratic and other assistance to members. Together, these three factors underscore that withdrawal is not strongly linked to the domestic politics of nationalism but is instead motivated by geo-political factors related to a state's preferences and IGO characteristics. These findings stand up against a host of alternative explanations and are robust to using different model specifications, estimations, and other robustness checks.

Our research engages scholarship on the backlash against the liberal world order ${ }^{16}$ and the recent pattern of retreats by putting IGO withdrawals in historical context. Further, our research contends with critical questions of when international law constrains leaders and how institutions affect state behavior. Our findings are also important for international relations theory because they question multiple paradigmatic understandings of international organizations. Skeptics contend that international agreements and organizations may be shallow if they only codify actions that would take place even in their absence ${ }^{17}$ But if this were true, states would not invest the time and cost to formally withdraw from an IGO when they could

${ }^{16}$ Ikenberry 2018; Kagan 2017.

${ }^{17}$ Downs, Rocke, and Barsoom 1996. 
otherwise just stay in an IGO that does not substantively change states' behavior. That states exert effort to formally withdraw from an IGO suggests that the organization might be pushing them to do something other than what they would do in its absence. On the other hand, institutionalist arguments ${ }^{18}$ suggest that international agreements can shape future state actions. ${ }^{19}$ However, if states can withdraw from IGOs when they see fit, we must ask whether IGOs really have the power to alter state behavior in the first place. Our research also speaks to constructivist arguments about the ability for IGOs to socialize member states. While international institutions may help converge state interests over time,${ }^{20}$ our research shows that outlier states who diverge in preferences are more likely to withdraw, casting some doubt on the logic of socialization.

As articulated above, our research also shows that there may be differences between public opinion toward international dis-integration and states' actual policy decisions regarding IGO withdrawal. Rising populist nationalism may indeed increase demands for IGO withdrawal, but politicians may be more constrained in translating these sentiments to actual IGO exits when they find themselves deeply enmeshed in the organization. We might therefore caveat the lefthand corner of the $2 \times 2$ table in the introduction to read "sentiment toward withdrawal" rather than just "withdrawal."

The paper proceeds as follows. We first provide background on IGO withdrawals conceptually and empirically, describing the first systematic collection of data on IGO withdrawals. Next, we outline three potential sets of withdrawal explanations that are derived from the IGO accession literature including domestic politics, IGO characteristics, and geo-

\footnotetext{
18 See, for example, Abbott and Snidal 2000; Simmons 2000; Keohane 1984.

${ }^{19}$ See, for example, Pevehouse 2002.

${ }^{20}$ Bearce and Bonadello 2007.
} 
politics. We then detail our research design and discuss the results and robustness checks. We conclude with implications for international relations scholarship and ideas for future research.

\section{Background on IGO Withdrawals}

IGO withdrawal occurs when a member state voluntarily removes itself from all contractual obligations and legally terminates its membership. We define an IGO according to the criteria in the Correlates of War IGO (COW IGO) dataset in order to examine retreats from legalized agreements with an independent secretariat. ${ }^{21}$ Withdrawal is a unilateral act, requiring no consent or approval from other member states. States withdraw by providing notice to other member states, then waiting a required timeframe for the IGO to formalize the request. The mode notice period given in IGO charters is one year. ${ }^{22}$

The possibility of withdrawal from IGOs is quite broad across institutions. The Vienna Convention on the Law of International Treaties (1969) establishes that states can legally withdraw when an IGO covenant explicitly outlines withdrawal terms. As we discuss in the empirical section below, about sixty percent of IGOs have a withdrawal clause. Additionally, a state may withdraw from a treaty without a withdrawal clause when all parties agree. Further, the Convention recognizes that a member state may withdraw due to a 'fundamental change in circumstances' which 'constituted an essential basis of the consent of the parties to be bound by the treaty.' These provisions mean that if a state wishes to withdraw from an IGO, it can do so

${ }^{21}$ Pevehouse et al. 2019. In the conclusion we suggest ways that this IGO definition might matter, and possibilities for future research to examine exits from other forms of international cooperation.

22 Authors' calculation based on original data. 
with enough time and documentation (even if the process is not always clear on how this is accomplished, as seen with the case of Brexit).

Since World War II, member-states have withdrawn from IGOs more than 200 times. To put this in context, there were 213 coups d'état and 548 interstate wars over the same time period - events that have garnered significant attention by scholars. ${ }^{23}$ This frequency of withdrawal translates into 2 percent of country-years or 0.04 percent of IO-member-years and underscores an important point: most states actually remain in the IGOs they join and withdraw rarely. Previous research illuminates explanations for this pattern: treaties' "flexibility devices" 24 — including reservations, ${ }^{25}$ duration and amendment rules, ${ }^{26}$ escape clauses, ${ }^{27}$ and dispute settlement mechanisms ${ }^{28}$ - can help states address concerns before they withdraw. ${ }^{29}$ Moreover, states often get what they want by threatening to withdraw. Still further, as articulated earlier, dissatisfaction in the IGO alone is unlikely to lead a state to withdraw, particularly if remaining a member is not very costly. ${ }^{30}$ Instead, a state can improvise ways to cut back its commitments while still remaining a member, for example, by reducing funding or changing its focus to other IGOs. ${ }^{31}$

${ }^{23}$ Authors' calculation based on Marshall and Marshall 2017; and Maoz et al. 2018.

${ }^{24}$ There is no data source to cover a sufficient number of COW IGOs to test this idea across a wide range of IOs. DESTA contains data on treaty flexibility provisions but these are mostly bilateral treaties, not IGOs. Koremenos (2016) contains just a sample and small fraction of our set of IGOs.

${ }^{25}$ Helfer 2006; Hill 1982.

${ }^{26}$ Aust 2013.

${ }^{27}$ Rosendorff and Milner 2001.

${ }^{28}$ McCall Smith 2000.

${ }^{29}$ Hirschman's (1970) Exit, Voice, and Loyalty also provides an informative framework for understanding the various choices states face.

${ }^{30}$ See Gray 2018 on "zombie" organizations.

${ }^{31}$ Membership withdrawal might be considered 'the final straw.' This paper does not address instances when a state engages in less significant departures such as no longer participating in the IGO's work or meetings, withdrawing from IGO projects or conferences, withholding IGO contributions, or lowering the diplomatic rank of meeting attendees (see Online Appendix for 
Still, this number of IGO withdrawals is a large number when considering that states have sunk costs in the IGO, including already having paid for policy changes (economically and politically) that were necessary to join the institution in the first place. In light of the previous data, withdrawal is out-of-equilibrium behavior, which is worthy of investigation. Thinking of it this way, IGO withdrawals can be seen as analogous to the bargaining theory of war which posits that states have incentives to negotiate peaceful solutions for conflicts of interests rather than to engage in costly wars (or here, withdrawals). ${ }^{32}$ Moreover, withdrawals are an important phenomenon because they may have large implications for individual countries' policies and world politics. ${ }^{33}$

Figure 1A illustrates the frequency of IGO withdrawals over time. The right axis and solid line indicate the number of withdrawals, while the left axis and dotted line show the number of IGOs. While the number of IGOs has increased since 1945, so have IGO withdrawals from around 2 organizations per year before 1980 (the mid-point in our data) to about 3.5 organizations per year after 1980. But as Figure 1B shows, most of the increase is due to the increasing number of IGOs. Although Drezner (2017) argues that withdrawal is an "increasingly popular exit option for global governance, ${ }^{\prime 34}$ the normalized rate of actual IGO withdrawals is fairly constant over time (save for a couple of outlier years after WWII). It is thus important to understand historic instances of IGO withdrawals to better describe the broader phenomenon as well as explain its causes.

examples). Likewise, withdrawal from treaties unrelated to IGOs are not included in this study (see Penney 2002).

${ }^{32}$ See, for example, Wagner (2000) for an overview of bargaining theory and Walter (2009) on civil wars.

${ }^{33}$ Chayes and Chayes (1991: 316) also remind us that we should not expect withdrawals often.

${ }^{34} \mathrm{See}$ https://www.washingtonpost.com/news/posteverything/wp/2017/06/21/the-increasinglypopular-exit-option-for-global-governance/?utm term=.8163e5dde510. Accessed July 2, 2017. 
[FIGURE 1A and 1B ABOUT HERE]

Figure 2 illustrates that the US, Canada, and the UK are the most frequent withdrawers since 1945 but many other states have exited IGOs as well, indicating that withdrawals are not isolated to these powerful countries. For example, Indonesia, Poland, Panama, and Thailand are also in the group of frequent withdrawers.

\section{[FIGURE 2 ABOUT HERE]}

Figure 3 shows the IGOs from which states have most frequently withdrawn since 1945 including the World Tourism Organization (WTouro) and International Whaling Commission (IWC). In the IWC, members' preference divergence with respect to specific quotas and bans on fishing seems to be behind many withdrawal decisions, as several countries left in 1982 and 1985, when new policy decisions regarding whaling restrictions were made and came into effect. ${ }^{35}$ In the WTouro case, several countries (like Australia) argued that their tourism policies no longer aligned with those of the organization - and that withdrawal would put them in alignment with other similar countries (like the UK, USA, New Zealand, Canada, Singapore, Ireland and Belgium). ${ }^{36}$ Both the WTouro and IWC cases align with our main finding that geopolitics, particularly a member state's preference divergence from other members, is an important factor in triggering IGO withdrawal. Apart from these two organizations, the many

\footnotetext{
${ }^{35}$ Author's interview with US-based IWC expert, July 2018.

${ }^{36}$ See https://www.ecotourism.org.au/news/australias-withdrawal-from-the-uns-world-tourismorganisation/. Accessed 17 October 2018.
} 
other cases show that IGO withdrawals span various organizations, world regions, issue areas, institutional size, and performance.

[FIGURE 3 ABOUT HERE]

Understanding IGO withdrawals is important because withdrawing can affect IGO funding, the IGO's future policy actions, and the subsequent unilateral action of the withdrawing state. ${ }^{37}$ For example, the US withdrawal from the International Labor Organization (ILO) in 1977 was consequential because the loss in membership dues of over US \$40 million represented $25 \%$ of the ILO budget, resulting in significant program and staff reductions. ${ }^{38}$ The US departure threatened the work of this specialized agency of the United Nations (UN) but also had the potential to "destroy the credibility and effectiveness of the UN system of organizations." 39 Withdrawal can also have significant consequences on the leaving state or remaining members. The U.S.' 2018 departure from the UN Human Rights Council, for example, 'removes Washington's voice in what human rights judgments to pass — so U.S. allies are now more likely to become ready targets. More importantly, it gives the U.S. little say in potential future reforms to the council's operations." 40

\section{Why do States Withdraw from IOs?}

${ }^{37}$ Most states still pay their IGO dues during notice and wait periods before they have officially withdrawn. This has important implications for international cooperation and compliance.

${ }^{38}$ Beigbeder 1979.

${ }^{39}$ Ibid. 
When examining the causes of recent salient IGO withdrawals, some observers have highlighted the role of increased nationalism. Some note that "the tide of rising nationalism is exacerbating the crisis of international cooperation" and that "in a world full of competing nationalisms, the landscape for interstate cooperation and global governance is deeply fractured. ${ }^{41}$ According to the nationalism argument, voters have increasingly supported historic enmities, territorial symbols, and traditional cultural values ${ }^{42}$ in contrast with integrationist values that are the cornerstone of many IGOs. Fukuyama (2016) argues that President Trump's nationalism both on economic policy and the global political system means that "he will seek to renegotiate existing trade agreements such as NAFTA and presumably the WTO, and if he doesn't get what he wants, he is willing to contemplate exiting from them."

Brexit—or the announced United Kingdom withdrawal from the European Union—-for example, seems to align with the nationalism reasoning. In 2014, Prime Minister David Cameron announced a referendum on the UK's membership in the EU. He hoped voters would quickly squash the idea, which would help maximize Tory votes in the general election. However, Cameron underestimated the share of voters who blamed the European Union for stagnant wages, immigration flows, and instability. Many of these voters turned to the nationalist UKIP party, which mobilized around the perceived incursions of the European Union into national politics and democracy ${ }^{43}$ The Guardian summarized that "the inexorable logic of Brexit is the logic of English nationalism." ${ }^{44}$

${ }^{41}$ Shukla 2018.

${ }^{43}$ See Farrell and Newman 2017.

${ }^{44}$ See https://www.theguardian.com/commentisfree/2016/jun/18/england-eu-referendum-brexit. Accessed 17 October 2018. 
Does nationalism explain IGO withdrawals beyond this handful of cases after 2014? We have reason to be skeptical. First, rising nationalism does not speak to the kinds of IGOs from which a state might withdraw, as illustrated in Figure 3. Can nationalism explain exit from lower-profile IGOs such as the World Tourism Organization? Second, states have been withdrawing from IGOs for decades and "historically, liberalism and nationalism have often been complementary." 45 Indeed, as Walter (2018) notes in work on European disintegration, "skepticism about the merits of international cooperation is nothing new."46 Moreover, questions abound regarding what really drives nationalism and whether this phenomenon is supply or demand-driven, prompting the need to study withdrawal as part of a broader phenomenon across time and space. Third, a large variety of states - including those without multiparty elections or nationalist parties - have withdrawn from IGOs. Nationalist sentiments affect a small share of countries, with support for integrationist principles quite robust in many other countries ${ }^{47}$ In sum, despite the salience of the nationalism argument for some recent cases, we argue that other factors explain the wider universe of IGO withdrawals over time.

One strategy in unpacking the conditions under which states withdraw from IGOs is a text analysis of the reasons governments cite when they leave. We have therefore inductively categorized the reasons states' quote for withdrawal, as shown in Figure $4 .{ }^{48}$

\section{[FIGURE 4 ABOUT HERE]}

\footnotetext{
45 Snyder 2019: 54.

${ }^{46}$ See also overviews in Hobolt and de Vries 2016; Kuo and Naoi 2015.

472016 Gallup survey; 2016 poll by the Pew Research Center.

${ }^{48}$ See online appendix for coding details.
} 
Several conclusions emerge from this inductive analysis. As Figure 4 shows, domestic political reasons for IGO withdrawals—of which nationalism is an aspect—are rare. Only five percent of withdrawals are categorized as "accused the IO of political overreach or sovereignty concerns" which align with nationalism. ${ }^{49}$ The most plausible contenders are Gambia's withdrawal from the Commonwealth in 2013 after receiving a negative verdict on its election quality by external observers, ${ }^{50}$ South Africa's withdrawal from UNESCO in 1955 after the organization's anti-apartheid publications, and Albania's withdrawal from the Warsaw Pact in 1968 after the Soviets invaded Czechoslovakia and violated the Warsaw Pact's principle of noninterference in national affairs.

Further, only three percent of withdrawals are linked to "changes in domestic politics." Only four percent of cases are "pre-emptive to avoid punishments" related to domestic-level political transgressions including gross violations of human rights, election standards, or a coup d'état. These withdrawals are face-saving measures to frame the withdrawal as moving away from an intrusive IGO and to avoid potential suspension for breaking the IGO's rules. ${ }^{51}$

The variety of other inductive explanations reinforces the notion that broader factors beyond domestic politics explanations such as nationalism may also be driving IGO withdrawals across time and space. The bulk of withdrawal cases - nearly one quarter - include reasons related to functional failures of the IGO including "costs," "dissatisfaction with IGO policies/ performance," and the IGO simply becoming "obsolete." Nonetheless, we are skeptical that these stated reasons reveal the full motivation for withdrawals. Since many voters support IGOs that

\footnotetext{
${ }^{49}$ See online appendix for examples of cases in each of the category and for coding criteria.

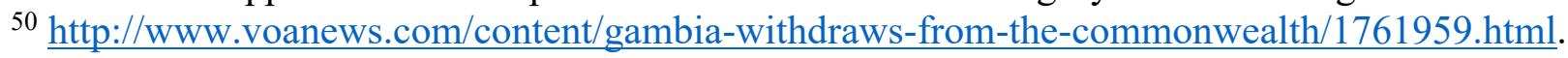
Accessed 22 May 2018.

${ }^{51}$ von Borzyskowski and Vabulas forthcoming.
} 
enhance cooperation in a particular issue area, politicians may argue that leaving might be justifiable if the IGO is failing in this regard. This could reframe withdrawal as the IGO failing to live up to its promises rather than the state reneging on an international commitment or veering away from the group's consensus which could have reputational consequences both domestically and internationally.

Another finding from Figure 4 is that in almost 13 percent of cases, politicians cited something related to "internal politics in the IGO" including using words like "politicization" or “ideological differences." Together with the two percent related to "war," four percent related to the "status of another member state," and four percent "no longer wanted to comply," these cases point to the importance of geo-political factors in IGO withdrawals. This suggests a need to study IGO characteristics as well as geo-politics of the withdrawing state vis-à-vis other member states in addition to domestic politics reasons.

Combined, these factors present an empirical puzzle. How should scholars make sense of IGO withdrawals across time and space? If observers cite nationalism as a driving force for recent IGO withdrawals but this does not seem to equally affect the past, and if politicians might misrepresent their reasons for exiting, then what factors drive the underlying process of IGO withdrawals? Scholars have not comprehensively examined IGO withdrawals, ${ }^{52}$ but several strands of literature on membership dynamics provide valuable insights and potential explanations. Using insights from the large literature of why states join IGOs, we outline three logics for why states might withdraw from IGOs, grouped around domestic politics, IGO characteristics, and geo-politics. There are no clear bright lines between these three groups which

\footnotetext{
${ }^{52}$ For example, in the Oxford Handbook of International Organizations (Cogan, Hurd, and Johnstone 2016), none of the 55 chapters focuses on the dissolution of IGOs, although Pevehouse and von Borzyskowski (2016) mention exit in the overview chapter.
} 
may intersect and overlap. Our aim is not to establish battle lines between these three logics but to help organize our conceptual thinking regarding the micro-foundations of withdrawal. ${ }^{53}$

\subsection{Domestic Politics}

Observers' recent arguments about nationalism and populism as a driver of IGO withdrawals emphasize the role of domestic politics, so we begin with a set of domestic politics arguments for why states may leave IGOs. The domestic politics-IGO accession literature from which we build uses the frame of two-level games ${ }^{54}$ to note that leaders can leverage international negotiations to help them get what they want at home. In other words, IGO membership has electoral consequences. Therefore, leaders may make IGO membership decisions to not only increase international cooperation but also to satisfy key domestic constituents.

These domestic politics arguments about the propensity of states joining IGOs suggest several observable implications for IGO withdrawal. First, countries at different levels of the democracy spectrum use IGOs differently. ${ }^{55}$ Highly consolidated democracies might therefore be less likely to withdraw from an IGO because they are more likely to suffer audience costs at home and abroad for reneging on international commitments. ${ }^{56}$ On the other hand, highly consolidated democracies may not need the signaling logic of IGOs as much as other kinds of

\footnotetext{
${ }^{53}$ While this is a productive way forward, we recognize potential limitations of leaning heavily on accession theories: some studies find that alliance termination contrasts with formation (Leeds and Savun 2007; Orbell et al 1984) and European disintegration is not simply "integration in reverse." See Jones 2018; Schneider 2017.

${ }^{54}$ Putnam 1988.

${ }_{55}^{55}$ Simmons and Danner 2010; Pevehouse 2002; Donno 2010; Mansfield and Pevehouse 2006.

${ }^{56}$ McGillivray and Smith 2000; Fearon 1997; Smith 1995, 1998. It is worth noting, however, that most of these reputational arguments come from the crisis bargaining literature - not from research on cooperation. C.f. Kertzer and Brutger 2016.
} 
states that need an external hand-tying mechanism for reforming policy, as the IGO accession literature suggests, so they may be more likely to withdraw. Transitional democracies may also point in both directions regarding the likelihood of withdrawal: given that transitional democracies sometimes join IGOs to signal reform, they might be less likely to withdraw. However, because they might not immediately qualify for access to prestigious IGOs at the start of their democratization trajectory, ${ }^{57}$ they might first join less desirable IGOs then withdraw as they find 'better' alternative IGOs.

The domestic politics literature on IGO membership also shows that political parties differentially support foreign policies toward joining IGOs. ${ }^{58}$ This implies that changes in government ${ }^{59}$ could also precipitate IGO withdrawals. While frustration with an IGO might exist for some time, a new government's perceived mandate from a recent election-or even the underlying factors that lead to the government's election in the first place-may spur it to change previous policy toward IGOs. New governments have a powerful policy formation window during the honeymoon period (or first 100 days in office). Therefore, a state might be more likely to withdraw immediately after a change in government or election. Similarly, the alliance termination literature shows international cooperation is sensitive to changes in core supporting coalitions, and democratic political institutions moderate the effect. ${ }^{60}$

Last, research has shown that the ideology of the domestic political party in power affects a state's foreign policy decisions because the party reflects the underlying public opinion of

\footnotetext{
${ }^{57}$ Kaoutzanis, Poast and Urpelainen 2016.

58 Milner and Tingley 2011.

${ }^{59}$ Predictions are not clear with regard to the right-left dimension of government change. Isolationist parties tend to be right-leaning in the US and Europe; left-leaning in Latin America; and of unclear leanings in Africa and Asia.

${ }^{60}$ Gaubatz 1996; Leeds 1999; Lipson 2003; Martin 2000; Morgan and Campbell 1991.
} 
citizens toward 'internationalist' foreign policy or 'isolationist' foreign policy. ${ }^{61}$ The political party in power may therefore affect the likelihood of IGO withdrawal too. In particular, when Nationalist parties are in office, they may be more likely to push for IGO withdrawal because they tend to blame international engagement for problems at home. ${ }^{62}$ Nationalist parties often campaign against international institutions in order to avoid the negative ramifications of interconnectedness. These domestic level arguments lead to the following hypothesis on the likelihood of IGO withdrawal:

H1 Domestic politics: IGO membership withdrawal should be more likely for states that have nationalist representation, have a change in government, or are less democratic.

\subsection{IGO Characteristics}

In contrast to domestic politics reasons, states might also withdraw from organizations due to the IGO's characteristics and functions. Functionalist IGO accession literature emphasizes that states join IGOs to enhance cooperation for a particular issue, so states may want to withdraw from an IGO that no longer functions as a state would like. ${ }^{63}$ Therefore, states may be more likely to withdraw from an IGO that no longer supplies institutional benefits such as information provision, ${ }^{64}$ centralization, and independence ${ }^{65}$ in a way that outweighs the costs of being an IGO member. Just as failing firms can cause shareholders to walk away, ${ }^{66}$ poor IGO performance may also trigger a member state to exit. Moreover, an IGO's 'failed functions' may

\footnotetext{
${ }^{61}$ Milner and Tingley 2011.

${ }^{62}$ See Copelovitch and Pevehouse, this Issue.

${ }^{63}$ See Haftel and Thompson (2018) on a similar logic explaining that states renegotiate treaties when they are not functioning as they had hoped.

${ }^{64}$ Keohane 1984.

${ }^{65}$ Abott and Snidal 1998.

${ }^{66}$ Hirschman 1970.
} 
range widely and differ by the nature of the cooperation problem, so the propensity of IGO withdrawals may depend on the issue area. Walking away from a security commitment may fundamentally change a nation's threat perception ${ }^{67}$ whereas walking away from an IGO focused on social issues may be easier (and therefore more likely) because it is not related to high politics. Many of these IGO-characteristic arguments in the IGO accession literature stress the shared benefits that IGOs can bring member states. Since they argue that states will be more likely to cooperate when they share common preferences, the lack of common interests - for example when the IGO is not made up of a densely democratic group of states - may make states more likely to withdraw. States in a less densely democratic IGO may also not feel their hands are "as tied" to the IGO commitment and lack the same sort of socialization mechanisms. ${ }^{68}$

Furthermore, the IGO accession literature emphasizes the heterogeneity of IGO designs and suggests several patterns regarding IGO withdrawal. States might be less likely to withdraw from highly structured IGOs if these are the best institutions at achieving the centralized administrative support and independence ${ }^{69}$ that states sought in the first place. Once states have invested in costly institutionalization, their continuing value may make institutionalized organizations particularly lasting and able to adjust to new challenges ${ }^{70}$ Moreover, these highly structured organizations may deeply entwine member states and make it more difficult to exit. These arguments about IGO characteristics stress the functional benefits of organizational membership and the importance of institutional design, leading to the following hypotheses:

\footnotetext{
${ }^{67}$ Leeds and Savun 2007.

${ }^{68}$ Pevehouse 2002.

${ }^{69}$ Boehmer, Gartzke and Nordstrom 2004; Karreth and Tir 2012.

${ }^{70}$ See Haftendorn, Keohane, and Wallander (1999) on a similar logic with regard to the institutionalization of alliances. On the other hand, states may be more likely to withdraw from highly institutionalized IGOs that have established too much independent agency or established a 'runaway bureaucracy' that stands apart from states' original intent.
} 
H2a IGO functionalism: IGO membership withdrawal should be more likely from IGOs that are less effective, are less densely democratic, or cover lower-stakes issue areas.

H2b IGO design: IGO membership withdrawal should be more likely from IGOs that are less institutionalized.

\subsection{Geopolitics}

In addition to these IGO characteristics arguments, geo-political explanations are important in understanding IGO membership. Overall, geopolitical factors emphasizes that a state's preferences in relation to other member states can affect its membership in an IGO. ${ }^{71}$ Much of the research looking at the interrelationship between member state preferences and accession to organizations argues that IGOs help 'screen' for members whose foreign policy preferences already align with the preferences of other member states. ${ }^{72}$ Other research is more optimistic that IGOs can also help constrain states. ${ }^{73}$ If membership is based on states having common interests, then when a member state's preferences sharply diverge from other member states, it may no longer have 'common interests' and gain from being a member. These changes in a state's likeness with other members might therefore make it more likely to withdraw from an IGO to avoid being hurt by its policies.

Power also plays a central role in geo-political explanations of IGO membership because powerful states may construct IGOs to lock weaker states into a stable and predictable arrangement, reducing the need for potentially costlier coercion later. ${ }^{74}$ While powerful states

\footnotetext{
${ }^{71}$ See Davis and Wilf (2017) on geopolitical preferences affecting economic organization membership.

72 Downs, Rocke and Barsoom 1996; Jupille, Mattli and Snidal 2013; Gray, Lindstadt and Slapin, Forthcoming.

${ }^{73}$ Simmons 2000.

${ }^{74}$ Ikenberry 2000; Stone 2011.
} 
might be more likely to threaten to withdraw (to show other states that they have appealing go-italone options), ${ }^{75}$ they are often the states who set up the IGO in the first place and likely favor the bargain. Therefore, weaker states might be more likely to actually withdraw from an IGO if the institutional bargain does not favor them.

Changes in state power, particularly the rise of newly powerful states, are also important for IGO membership because shifting power is one of the classic "problems" in international relations theory. ${ }^{76}$ Gilpin (1983) argues that when a powerful state begins to decline, rising powers challenge the existing international order and may therefore calculate that they are at an institutional disadvantage in the IGO (and can do better through outside options). Rising powers may be more likely to withdraw rather than remain locked into a losing distribution of power.

Last, a lead state exiting an IGO may change the overall balance of remaining state preferences and create a contagion effect for withdrawal. Collective action theory shows the importance of privileged actors ${ }^{77}$ (such as hegemons ${ }^{78}$ ) in providing public goods, but once these leaders have left, remaining members may receive fewer collective benefits. Moreover, remaining members may have to shoulder more relative costs due to decreases in budgetary contributions as well as the IGO's legitimacy after a lead state departs. Since adjusting formal institutions is costly, states that remain after leaders have exited may also have difficulty reopening the institutional bargain within the organization. All of these factors combined may lead weaker states to exit after lead states have departed. ${ }^{79}$ Furthermore, a disintegration experience that improves the situation of the withdrawing country can create an "encouragement

\footnotetext{
75 Gruber 2005.

${ }^{76}$ Organski’s 1964; Carr 1964.

${ }^{77}$ Olson 1965.

${ }^{78}$ Ikenberry 2000.

${ }^{79}$ EU disintegration literature have also noted a potential contagion effect. See Walter 2018.
} 
effect" and make withdrawal "socially contagious." 80 These geo-political arguments lead to the following hypothesis:

H3 Geo-politics: IGO membership withdrawal should be more likely for states that are rising power, have diverging preferences, and have seen important states withdraw.

\section{Research Design}

\subsection{Universe of Cases, Unit of Analysis, and Dependent Variable}

We test our hypotheses in a statistical analysis of original data on IGO withdrawals from 1945 to 2014 worldwide. ${ }^{81}$ The dataset includes all 493 IGOs from the updated COW IGO dataset. ${ }^{82}$ Our unit of analysis is the IGO-member state-year because we are interested in how the characteristics of countries and organizations influence withdrawal. This unit of analysis is in line with other recent research on IGO membership dynamics. ${ }^{83}$

We leverage this original data for the dependent variable IGO withdrawal. It is coded 1 if member state $m$ decided to withdraw from IGO $i$ in year $t$, and 0 otherwise. We only code decision years as 1 because we are interested in what drives withdrawal decisions, not what accounts for the withdrawal's duration. Moreover, even though most IGOs have a waiting period after a state has announced a withdrawal until it becomes effective, we use the announcement date as it reflects when the decision has been made - and thus when the state and organization's characteristics should matter.

\footnotetext{
${ }^{80}$ Pacheco 2012.

${ }^{81}$ The availability of two domestic politics variables limits the timeframe in the domestic politics model to 1975-2014.

82 Pevehouse et al 2019.

83 Donno, Metzger, and Russett 2015; Poast and Urpelainen 2013.
} 
In order to compile the dataset of withdrawals, we searched Factiva, a prominent media database for historical newspaper articles that included both the IGO name of each active organization in the COW dataset and the words "withdr*," "exit" or "secession." Since we are interested in membership withdrawal, we focused on withdrawal of state membership from the IGO and excluded withdrawal of funds or delegations, as explained in the definition section and Online Appendix. To account for the relative rarity of withdrawals, we use rare events models. The results are substantively similar using logit models that we explain below in robustness checks.

We are confident that our search procedure makes the resulting IGO withdrawal dataset both consistent and comprehensive. We crosschecked every instance of IGO withdrawal by finding the newspaper article outside of Factiva as well as at least one supplementary article from a different media source. To mitigate further the risk of media under-reporting withdrawals due to differences in language or media efforts, we also checked each organization's website for information about membership withdrawal over time and followed up via email with each IGO. Finally, we crosschecked our original data with state-year-IGO membership in the Correlates of War database ${ }^{84}$ While we did not find any instances of cases that we had missed, the COW dataset seems to underreport membership gaps due to withdrawal, which may pose a challenge to previous papers that rely on these data for IGO membership changes.

In some cases, withdrawal is only documented at the date it comes into effect rather than the date of decision to withdraw. To ensure consistent coding for the timing of decision to withdraw, we also documented the charter stipulation for each IGO in terms of how many months have to pass between decision and effect. Details are in the Online Appendix.

${ }^{84}$ Pevehouse et al. 2019. 


\subsection{Independent Variables}

To evaluate our hypotheses, we include variables for the state's domestic politics, IGO characteristics, and geo-politics. For the domestic politics explanations, we use variables for a state's level of democracy, change in government orientation, and nationalism. Democracy captures the polity 2 score of each state in the previous year. Highly consolidated democracies may be more likely to suffer high audience costs when their leaders renege on international commitments, making withdrawal less likely.

Government orientation change is a binary variable coded 1 when government orientation changed between left, right, center, and 0 otherwise. This variable has a portion of missing values because many governments - especially in the developing world - cannot be easily categorized in this manner. When an election has just occurred, and a changed government is in power, the new government may be more likely to withdraw from an IGO to follow through on a mandate, or because it represents changed sentiments toward international commitments. Nationalism is coded 1 when the primary component of any party platform (executive, government, or opposition) is the creation or defense of a national or ethnic identity, and coded 0 otherwise. About 20 percent of the observations in our sample are coded nationalist. Examples include Austria since 1984, where the far-right and center-right parties (FPÖ, ÖVP) have been involved in every government; also Syria (since 1975) and Egypt (since 2012), both of which have withdrawn from international organizations. Both variables are sourced from the Database of Political Institutions (DPI), which in turn draws on information from several sources (Europa, Banks, Political Handbook, and the Agora website). Since DPI data are available beginning in 1975, which lowers the sample size of IO-state-years, we also run robustness tests without this 
variable. In sum, we expect democracy to be negatively signed and government orientation change and nationalism to be positively associated with withdrawal.

To evaluate the second set of arguments related to IGO characteristics, we include variables for $I O$ institutionalization, IO performance, IO average democracy score, and issue area. The first indicator, IO institutionalization, captures the degree of independent decisionmaking power, central monitoring, and enforcement capacity of the IGO. We source this variable from Karreth and Tir (2013), who build on earlier coding by Boehmer, Gartzke, and Nordstrom (2004) to categorize organizations into low, medium, and highly structured organizations. ${ }^{85}$ Countries may be less likely to withdraw from highly institutionalized organizations because they include the monitoring and enforcement capabilities that can help states achieve centralization, independence, information sharing, and economies of scale, among others.

IO performance captures the degree to which the organization achieves its objectives, is cost effective, and responsive to stakeholders. We source this variable from Lall (2017) who measures performance based on (averaged) British and Australian government evaluations of IGOs; these are government perceptions and proxy for the net value states ascribe to an organization. IO performance varies from 0.01 to 0.89 with higher values indicating higher performance evaluation. For example, the Commonwealth Secretariat is rated low performance (0.02), the ILO moderate $(0.24)$ and the WTO high performance $(0.89)$. While these data are the best operationalization of institutional performance known to us, they only cover 18 of the 493 IGOs, ${ }^{86}$ and thus dramatically lower the sample size. We thus conduct separate analyses for this

\footnotetext{
${ }^{85}$ Since the data cover 265 of the 493 organizations, which lowers the sample size of IO-stateyears by about a quarter, we also run robustness tests without this variable.

${ }^{86}$ Lall (2017) provides data for a total of 53 international bodies (organizations, programs, and funds); 18 of them are IGOs.
} 
variable. This data limitation also exists in practice, making it difficult for government agencies to systematically measure output or make a case against membership based on this. ${ }^{87} \mathrm{We}$ expect that states are more likely to withdraw from IGOs that have poor performance.

The variable $I O$ average democracy score is the democratic density among all members in the IGO in the previous year, excluding the relevant state itself. The calculation follows Pevehouse (2002a, 2002b) and uses the polity2 variable from the polity4 data (Marshall, Jaggers, and Gurr 2011). As articulated above, states may be more likely to withdraw from IGOs that have a low average democracy score because they may not have the same mechanisms to tie states' hands to policy reforms and they are also less likely to hand out benefits such as election assistance $^{88}$ or development aid.

We include the variable issue area because states might be more likely to leave some types of organizations based on the issue area and the nature of the cooperation problem. ${ }^{89}$ For example, states might be more reluctant to leave security-related organizations because doing so might pose a larger risk to their survival. We use COW IGO data to indicate whether the IGO focuses on political, economic, or security issues; economic is the excluded reference category. In sum, we expect the IGO characteristics variables - IO institutionalization, IO performance, IO average democracy score, and economic issue area - to have a negative coefficient.

To evaluate the third set of explanations that focus on geo-politics, we include variables for a state's preference divergence from the IO average, contagion, and change in state power. Preference divergence from $I O$ average measures the degree to which a state's voting in the United Nations diverged from the average voting behavior of other states in the relevant IGO in

${ }^{87}$ See for example State Dept 1997: 6.

${ }^{88}$ von Borzyskowski 2019.

${ }^{89}$ Koremenos, Lipson, and Snidal 2001; Koremenos 2016. 
the previous year. We source data from Bailey et al. (2017), which measures a state's positions towards the US-led international order. These data are advantageous as they conceptually relate to our outcome, measure preferences in a single dimension, and are comparable across time. As a state becomes more dissimilar in its preferences to other IGO members, it may be more likely to withdraw because it no longer shares in the collective mission.

Contagion is a binary indicator coded 1 when the lead state in the IGO has withdrawn from the same organization in the previous year, and 0 otherwise. We define a lead state as the largest economic power in the organization by GDP. We also use alternative indicators (including whether the founding member or regional power withdraw) in follow-on tests. A state may be more likely to withdraw when a lead state in the IGO already has because collective benefits may diminish while collective action challenges without a leader may increase.

To capture state power change, we use the difference in CINC scores from the previous to the current year that measure national military capabilities based on data from Greig and Enterline (2017) and Singer, Bremer, Stuckey (1972). ${ }^{90}$ We focus on military power instead of other types of power here because the arguments with respect to withdrawal (outlined above) center on military power. ${ }^{91}$ Positive changes indicate that states have become more powerful. Instead of looking at the level of power, this variable reflects that states may be more likely to withdraw as they gain power because they see their actual power as out of step with their formal power in the institution (which changes rarely). To sum up our geo-political factors, we expect preference divergence, contagion, and state power change to be positively associated with withdrawal.

\footnotetext{
${ }^{90}$ We scale the CINC score change (multiplying it by 100) to keep coefficients on a similar scale, which eases readability of coefficients.

${ }^{91}$ We also account for economic power with variables for GDP growth. See Appendix Table A3.
} 


\subsection{Control variables}

We include control variables to account for potential confounders. The control variables are Length of state membership in IO and IO size. Longer membership in the IGO might mean that state preferences or the IGO itself has had a greater chance of veering from its original intent leading to a higher likelihood of state withdrawal. At the same time, longer membership might also be associated with more preference divergence, the level of institutionalization, or more democratic density over time. ${ }^{92}$ Thus, membership length may confound the relationship between at least two predictors and the outcome. Length of IO membership is the (logged) number of years that state $m$ has been a member of IGO $i$ in the previous year. Similarly, IGO size may correlate with greater preference divergence and democratic density. IO size measures the (logged) and lagged number of other member states in the IGO.

Finally, we account for time dependence as recommended for binary time-series-crosssection analyses. ${ }^{93}$ All models include cubic polynomials for time since the last withdrawal in the respective organization. All independent and control variables are lagged by one year to mitigate endogeneity. Descriptive statistics for all variables are in Appendix Table A1.

\subsection{Model}

We estimate the following statistical model

$$
\text { Withdrawal }_{m t i}=\beta+\beta_{1} \mathrm{E}_{m t i}+\mathbf{X}_{m t i} \beta+\varepsilon_{m t i}
$$

where withdrawal is the dependent variable and $\beta_{1}$ is the parameter of interest on the key explanatory variables $\mathrm{E}_{m t i}$. Further, the vector $\mathbf{X}^{{ }^{\prime}}{ }_{m t i}$ represents a set of control variables, $\varepsilon_{m t i}$ is the

\footnotetext{
92 Barnett and Finnemore 1999.

${ }^{93}$ Beck, Katz, and Tucker 1997; Carter and Signorino 2010.
} 
idiosyncratic error, and the subscript $m$ stands for member state, $t$ for year, and $i$ for intergovernmental organization. The model is estimated using rare event logit to account for the relative rarity of the outcome ${ }^{94}$ and uses robust standard errors clustered on IGO to account for the lack of independence between countries within the same organization. In the robustness section, we replicate this with logit analyses and clustering on countries.

\section{Results}

Table 1 presents the results, showing estimates from rare events logit models. Column 1 shows the set of domestic-level variables, column 2 the set of IGO-level variables, column 3 the set of geo-politics variables, and column 4 is a fully saturated model.

\section{[TABLE 1 ABOUT HERE]}

Overall, Table 1 reveals interesting and important insights about states' withdrawals from intergovernmental organizations. The analysis provides limited support for domestic politics explanations (including nationalism), mixed support for arguments related to IGO characteristics, and fairly strong support for the set of geo-politics explanations (particularly diverging state preferences and contagion).

Across time and space, the set of domestic politics explanations receive limited empirical support. This is important and suggests that the recent wave of IGO withdrawals that seem to be occurring concomitantly with a rise in nationalism and populism should not be interpreted as an explanation for previous exits. Only the coefficient on democracy is statistically significant in

\footnotetext{
${ }^{94}$ King and Zeng 2001.
} 
columns 1 and 4. It is positive, indicating that more democratic countries are also more prone to withdraw from IGOs. To evaluate the substantive effect of the statistically significant factors, we calculate the predicted probability of withdrawal onset from model 4 . We put the substantive effects in context by comparing the predicted risk to the baseline risk of withdrawal. In terms of substantive size, a standard deviation change in democracy level (from 2.2 to 9.5) increases the baseline probability of withdrawal by $55 \%$. Recalling Figure 2 , the United States, Canada, and the United Kingdom - some of the world's most consistently highly rated democracies - are among the top withdrawers from IGOs over time. This finding may be perceived as being in contrast to the audience costs expectations that democracies may be less likely to renege on an international commitment. This is interesting because IGOs represent a different kind of international commitment than crisis bargaining which has comprised the bulk of this theory's testing.

Further, government orientation change is positive as hypothesized and borderline significant in column 4. Having a change in government orientation increases the baseline risk of withdrawal by $74 \%$. For example, US House and Senate support for the International Exhibitions Bureau (BIE) waned for several years in the late 1990s with the US even failing to appropriate funds to the organization. Nevertheless, President Clinton did not push to exit the organization. When the George W. Bush Administration came into office in 2001, it touted US withdrawal from the BIE's 1928 Paris Convention as one of the Administration's early foreign policy accomplishments. ${ }^{95}$

While the coefficients on democracy and government orientation change are statistically significant, this seems to be mainly driven by these three most frequent withdrawers. Dropping

${ }^{95}$ Charnovitz 2017. 
the top three withdrawing states - the United States, the United Kingdom, and Canada - erodes the effect of democracy and government orientation change on withdrawing; this is perhaps not surprising, as all three states are advanced democracies with frequent turnovers and are members of many IGOs. Other results are substantively unchanged (table not shown).

The other indicator for domestic politics - nationalist - is not statistically significant. Given that many observers have recently linked increasing nationalism to IGO withdrawals, we investigate this variable further for potential time trends. We conducted follow-on analyses to restrict the sample to the post-Cold War period (since 1990), and parsed out nationalist in terms of whether it matters if a nationalist party was in the executive, in government, or in the opposition, as these might be associated with discrete dynamics. ${ }^{96}$ As another alternative measure, we have also used populism, which has also been invoked many times by contemporary observers to explain withdrawals particularly in recent years. Populism data are assembled from multiple conventional data sources but are limited to Europe and Latin America. ${ }^{97}$ We restrict analyses to post-1990, since nationalism and populism have been on the rise again since then; however, results do not depend on this decision and are essentially identical using the full time frame since 1945. None of these coefficients gain statistical significance, regardless of these various coding decisions (see Appendix Tables A7). The results are summarized in Figure 5 below. While the coefficients are mostly positive, indicating a tendency for more nationalist parties to be more likely to withdraw from international organizations, none of them are statistically significant.

\footnotetext{
96 This is also based on DPI data and its nationalism and vote share variables for the executive, government, and opposition. We replicated Table 1 model 1; replicating model 4 yields quite similar results.

${ }^{97}$ We use data from Hawkins and Kaltwasser 2017; Huber and Schimpf 2016; Houle and Kenny 2018; Huber and Ruth 2017.
} 


\section{[FIGURE 5 ABOUT HERE]}

It is of course possible that economic factors are an omitted variable in the domestic politics explanation above. Economic factors may drive nationalism or preference divergence; and they may also drive withdrawal. For example, low economic growth rates may trigger IGO withdrawal due to budget cuts or decreasing state power. Further, economic hardship may trigger public discontent with economic integration and international institutions more broadly, thus increasing isolationist actions. To mitigate the omitted variable issue, we add two economic control variables: GDP growth and unemployment. We source data for both variables from Graham and Tucker (2015), which in turn rely on World Bank data. ${ }^{98}$ The results are in Appendix Table A3. GDP growth is negatively associated with withdrawal and is weakly significant in two models, pointing perhaps to recessions and budget crackdowns as trigger events for IGO withdrawals. We conclude that economic recession may make states more prone to withdrawal. Thus, nationalist explanations for withdrawal may instead be masking or missing underlying economic crises.

Of course, it is also possible that lagging growth could raise a common factor problem in that it may both drive nationalism and withdrawal. If that were the case, just including growth as a control could generate post-treatment bias. Comparing results in Table 2 and Appendix Table A3, we note that this bias seems negligible because the size of the coefficient changes but the direction and non-significance of the nationalism indicator remains. To further mitigate the

\footnotetext{
${ }^{98}$ We do not include this variable in the main analysis because it is only available since 1960 , which restricts the sample size and temporal coverage across models.
} 
possibility of the common factor issue (spuriousness), we used coarsened exact matching (CEM). The idea behind matching is to generate a more balanced dataset and in particular find pairs of observations which were relatively similar across a range of variables (including growth) but differ in nationalism. Replicating Table 2 model 1 with growth and CEM yields the same substantive insight: nationalism is positively but not significantly associated with withdrawal..$^{99}$

To summarize, while increasing nationalism and populism are often cited in explanations of recent cases such as Brexit and US withdrawal from UNESCO, nationalism is not an important driving factor for IGO withdrawals across time and space. Moreover, we note that recent cases may be better explained by other underlying developments such as the country's preference divergence vis-à-vis other member states or economic recession as explained above. Identifying these underlying factors is an important part of establishing a more general theory of IGO withdrawals.

Explanations related to IGO characteristics receive mixed support. On the one hand, an organization's performance and democratic density influence withdrawal: states are significantly less likely to leave organizations with more democratic members than those with less democratic membership. In terms of substantive magnitude, increasing IO's average democracy level by one standard deviation from the mean - from 2 to 6 average on the polity 2 scale - decreases the baseline probability of withdrawal by $30 \%$. This might speak to the benefits that states gain from densely democratic IGOs, be they material (for example, democracy assistance) or reputational

\footnotetext{
${ }^{99}$ Iacus, King, and Porro 2012. We use five cutpoints for polity and growth, and one cutpoint for government orientation change. The balanced dataset has a multivariate L1 distance of 0.65 , far from perfect imbalance of 1 . Using the generated CEM weights, the p-value of the bivariate rare events logit estimate is 0.8 and of the multivariate rare events logit (including controls to further improve balance) is 0.7 .
} 
from belonging to part of a more democratic club (which can also have financial benefits). ${ }^{100}$ For example, the United Kingdom is the first state to withdraw from the densely democratic European Union with an average democracy score of 9.6, making it an outlier. On the flipside, Eritrea (2009), Morocco (1984), and Zaire (1992 and 1984) have all withdrawn from the African Union with an average democracy score of 1.9 in 2009 (and below -2 in the 1980s and 1990s).

There is also support for the intuitive notion that better performing or more effective organizations are less likely to be deserted. In Appendix Table A2, the coefficient on $I O$ performance is consistently negative and highly significant. Substantively, a one standard deviation increase in organizational performance makes withdrawal $66 \%$ less likely. For example, no state has ever withdrawn from the World Trade Organization - and it has one of the highest performance indices (0.89) of IGOs in the sample. On the other hand, the Food and Agriculture Organization and International Labor Organization (ILO) - with lower performance indices of 0.22 and 0.24 - have both experienced frequent state exit. However, recall that this finding is based on a limited sample of 18 organizations for which performance data is available, so this insight - while intuitive - might not transfer to the broader set of organizations.

Beyond performance and democracy benefits, the other two indicators of IGO-level explanations all have non-significant coefficients: IO institutionalization and issue area are not significantly associated with withdrawal. This casts doubt on IGO characteristics broadly as a driving force for withdrawals.

In contrast, two of the geo-politics explanations receive strong support, underscoring the importance of an aggrieved state's preferences in relation to other member states when considering IGO withdrawals. The coefficients on preference divergence from other IO members

${ }^{100}$ Gray 2013. 
and contagion within the organization are consistently highly significant and positive, suggesting that preference divergence and contagion increase the risk of IGO withdrawal. For example, several states have withdrawn from the Non-aligned Movement (NAM) during the Cold War including Myanmar and Argentina as their preferences diverged from the aims and missions of the average NAM member states. Substantively, a one standard deviation increase in preference divergence between a state and the IGO membership at large is associated with an $93 \%$ increase in the baseline risk of withdrawal.

With regard to contagion, the coefficient is positive and highly significant. It is also substantively important: if the biggest economic power in the organization withdraws, it increases the baseline probability of further withdrawals from the same organization by a factor of 23. This is a very strong effect on the likelihood of IGO withdrawal. For example, after the United States withdrew from the UN Industrial Development Organization in 1995, 12 states followed suit in a virtual domino effect. In follow-on tests, we replace the contagion measure (withdrawal by lead state in $I O$ ) with contagion in two other forms: withdrawal from founding member in IO and withdrawal from regional power. Like the main indicator, these two coefficients are positive and consistently significant; they are also of similar size (see Appendix Table A4). This is strong evidence in support of contagion effects, be they from economically powerful members in the organization, in the region, or IGO founding members. The coefficient on state power change is significant in column 3 but not column 4. It is negative, indicating that rising powers may be less likely to withdraw from international organizations.

The control variables behave largely as expected. IO size is significant in several models and negative, indicating that larger organizations are associated with a lower risk of withdrawal. This is in line with Figure 3: while there are a handful of universal organizations from which 
countries withdraw, many of the affected organizations are regional and smaller institutions. Length of membership in the organization is not consistently significant.

Why might the set of geo-political explanations stand out vis-à-vis domestic politics and IGO characteristics for explaining withdrawal? The set of geo-political factors may be the strongest explanations of IGO withdrawal because a country that no longer shares common interests with the group may have very little influence in the IGO's operations by staying in the IGO. Indeed, this state may end up being stuck with a collective policy that works in opposition to their desired preferences, and thus staying in the organization stands to erode its sovereignty by pushing international policies in the opposite direction. On the other hand, our results suggest that for the most part, states may remain in IGOs that have characteristics they dislike because they might find other ways of handling design-level critiques or efficiency problems. For example, states may choose to cut back country-level contributions or even just let the IGO sputter along (even if it is not accomplishing much). More optimistically, aggrieved states might collectively work to fix IGO inefficiencies within the IGO instead of withdrawing. In other words, even if the IGO is not perfectly performing its functions, inertia and sunk costs of its may lead states to stay in, particularly when this is a rather costless choice. One interpretation of our results is that the high opportunity cost of creating a new organization may provide a hurdle to IGO withdrawal except when the state's preferences make them an outlier compared to other members. This means that for the most part, leaders choose to stay in IGOs, even if domestic political support for the IGO might have ebbed, as shown through nationalists being in power. If the state's leader is unhappy with a previous IGO deal, she may nonetheless feel her hands are still ' tied' and stop short of actually withdrawing from the IGO. 


\section{Robustness}

We ran several follow-on tests to check the robustness of our results: changing the sample, the model specification, and the estimation. These robustness checks leave the main results largely unaffected.

First, we changed the sample in several ways because some of the control variables have missingness, so that estimates across columns in Table 1 are based on different samples. To ensure that differences in estimates between individual models (column 1-3) and the saturated model (column 4) are due to changes in control variables rather than changes in sample composition, we replicate Table 1 by restricting the sample to that in column 4 also for columns 1-3. The results are substantively quite similar (see Appendix Table A5). We also check whether results differ during or after the Cold War, separately examining the periods 1945-1989 and 1990-2014 (see Appendix Tables A6-7). The Cold War period might be different because aspects like states' democracy levels played less of a role (than say, being communist or capitalist) and preference divergence within organizations was limited due to the bloc structures. During the Cold War, only the geo-politics variables seem to matter: only contagion, preference divergence and state power change explain withdrawal. However, we should also keep in mind from Figure 1 that withdrawals are more common (in absolute numbers) after 1990. Results on the post-1990 observations are quite similar to the main results in Table 1.

Second, we change the model specification by dropping two variables due to high missingness and adding four potential confounders for domestic politics, IGO characteristics, and geo-politics. Two explanatory variables have missingness and thus restrict the sample size. Government orientation change draws on DPI data, which only starts in 1975, so that results in columns 2 and 4 are based on a temporally limited sample (1975-2014 instead of 1945-2014). 
Further, the IGO institutionalization measure is not available for a subset of organizations, which restricts the estimation in columns 1 and 4 . To ensure that results for the remaining explanatory variables are not influenced by the change in temporal or IGO restrictions, we replicate Table 1 by dropping these two variables (see Appendix Table A8). Our results for preference divergence and contagion are robust; $I O$ average democracy score loses significance.

We also add four controls. We added UN specialized agencies because several case studies focus on organizations like the ILO and UNESCO. ${ }^{101}$ These UN specialized agencies are indeed more prone to withdrawal, but accounting for this trend does not change our main results (see Appendix Table A9).

We also added three other potential confounders: state power, IO withdrawal clause, and political backsliding. We add state power because powerful states are often the founding members and likely favor the institutional bargain. ${ }^{102}$ Furthermore, powerful states might be more democratic, and thus confound the relationship at least between domestic predictors and withdrawal. We added Withdrawal clause because its presence may affect the likelihood of withdrawal given the process is clear and pre-negotiated rather than ad-hoc. ${ }^{103}$ Moreover, withdrawal clauses might be associated with more institutionalization. Withdrawal clause is a binary variable indicating whether the IGO charter or founding covenant contains a withdrawal clause. ${ }^{104}$ About 60 percent of IGO charters contain a withdrawal clause. We added Political backsliding because states may be more likely to withdraw from an IGO after political

\footnotetext{
${ }^{101}$ C.f. Imber 1989.

102 Ikenberry 2000; Stone 2011; Johnson 2014. Powerful states, however, might be more likely to threaten to withdraw (because they have appealing go-it-alone options).

${ }^{103}$ Helfer 2005; Koremenos and Nau 2010. See also Rosendorff and Milner 2001, Kucik and Reinhardt 2008, and Pelc 2009 for how exit clauses may disadvantage the withdrawing state. 104 Details provided in the Online Appendix.
} 
backsliding to pre-empt punishments such as sanctions or membership suspension. At the same time, political backsliding is correlated with the country being less democratic and having a government change. We therefore include Political backsliding as a binary variable coded 1 if any of the following apply: a two-point or larger reduction in human rights or Polity2 scores compared to the prior year, a successful coup d'état, or serious election irregularities (unacceptable election quality, major election problems, and government harassment of the opposition) and 0 otherwise. ${ }^{105}$ Accounting for these additional potential confounders does not change the results (see Appendix Table A10).

Third, we changed the estimation from rare events to (ordinary) logit models because this data feature may unduly influence our results. We replicate Table 1 using logit in Appendix Table A11 and our results are robust to the change in estimation. Lastly, we cluster standard errors on countries instead of organizations; this does not affect the results (see Appendix Table A12).

\section{Conclusion}

Recent observers point to nationalism as a domestic politics explanation for the current "wave" of IGO withdrawals. As Haas (2018) argues, "Nationalism is a tool increasingly used by leaders to bolster their authority, especially amid difficult economic and political conditions. And

${ }^{105}$ We source human rights data from Gibney, Cornett, Wood, and Hashke 2013; polity2 data from Marshall, Jaggers, and Gurr 2010; coup data from Marshall and Marshall 2012; government harassment of opposition from Hyde and Marinov 2011, and data on unacceptable election quality or major election problems from Kelley 2010, 4-5. A 2+ point reduction in human rights or Polity2 indexes is large enough to eliminate measurement errors (which could occur as a result of one- point fluctuations that might reasonably occur on a year-to-year basis) and small enough to capture real-world events (where a two-point drop has been enough to trigger discussions about institutional sanctions). The $2+$ point reduction also means that we are agnostic about where the country is on the democracy scale. 
global institutions have failed to adapt to new power balances and technologies." However, we argue that while the America First "withdrawal doctrine" and Brexit seem related to nationalism, we need to be careful in extrapolating this explanation to inform a broader, historical understanding of IGO withdrawals.

This paper therefore explains the conditions under which states withdraw from IGOs by making both a theoretical and an empirical contribution. By leaning on the prolific literature related to IGO membership accession, we derive observable implications for when IGO withdrawal might be more likely. We argue that nationalism - and other domestic political factors - are not a driving force for IGO withdrawals across time, even if this might be a salient explanation for recent cases. Instead, we argue that geo-political factors are integral to understanding when and why states withdraw from IGOs. First, when a state's preferences diverge from average preferences in the institution, that state is more likely to withdraw. Moreover, contagion makes IGO withdrawal more likely: when important countries - including founding members, regional powers, or economic hegemons -- lead the way in withdrawing, other states often follow so that they are not left with an inflated burden and fewer benefits. The state-level makeup of the IGO also affects withdrawal: states are far less likely to withdraw from densely democratic IGOs because these institutions are perhaps more effective at tying states' hands to their commitments. We test our argument with the first systematic data on over 200 IGO withdrawals covering 493 IGOs over the last 70 years and find strong evidence supporting our claims. Rising populist-nationalism may lead to increased public opinion pushing for IGO withdrawals - as the framework for this Special issue suggests - but this does not necessarily equate with an increase in actual IGO withdrawals which tend to be rare and driven by geopolitical factors. 
Exploring the empirical terrain of when and why states withdraw from IGOs lays foundations for future research including understanding the effects of withdrawals. First, given that political leaders often release a public statement when they withdraw from IGOs, how can we better understand the various frames that they use and their relation to public opinion? Relatedly, do other member states punish withdrawers — either materially or politically—for exiting IGOs, even though this is a legally sound mechanism for pulling back from an international agreement? Moreover, do IGOs change policies when states exit to curry favor and attract the withdrawn state back? Future research should systematically study these questions across the broad set of IGOs in our original dataset.

Future research should also examine member state withdrawals beyond this paper's focus on formal IGOs because states are increasingly cooperating through alternative institutional arrangements such as informal IGOs. ${ }^{106}$ As this paper has shown, withdrawals from formal IGOs are relatively rare, which may speak to the high costs or complexity of exiting organizations that have formal, organizational footprints. On the other hand, the increasing use of other modes of global governance may be one way that states mitigate against this entrapment; indeed, the U.S.' recent withdrawals from the Paris Climate Accord and Iran Nuclear Deal fall into this category. Understanding when states withdraw from IGOs presents lessons for both defenders and skeptics of treaty compliance. If states are more likely to withdraw from IGOs when they have outlier preferences vis-a-vis other members, then skeptics regarding the power of international law to constrain states may feel supported. Our results may suggest that IGOs have less ability to socialize states whose preferences largely veer from average member-state preferences. Moreover, the strength of the contagion effect may be troubling: weaker states do follow leaders

${ }^{106}$ Vabulas and Snidal 2013. 
withdrawing from IGOs, and thus the risk of a domino effect following a hegemon's departure is real.

Yet this study is cautiously optimistic about the resilience of IGO membership. By examining IGO withdrawals over time, we have shown that IGO withdrawals do not happen frequently and they have not been increasing drastically over time. Historically - and even in the contemporary era - international cooperation and nationalism can and have existed alongside each other. Moreover, the company states keep in IGOs, particularly when members are embedded in densely democratic organizations, seems to tie member states to their commitments. While some states have said "hello" then "goodbye" to IGOs, withdrawing does not appear to be an easy response amidst waves of nationalism. 


\section{Bibliography}

Abbott, K. W., \& Snidal, D. 1998. Why states act through formal international organizations. Journal of conflict resolution 42(1): 3-32.

Abbott, K. W., \& Snidal, D. 2000. Hard and soft law in international governance. International organization 54(3): 421-456.

Aust, Anthony. 2013. Modern treaty law and practice. Cambridge University Press.

Athanassiou, P. 2009. Withdrawal and expulsion from the EU and EMU: Some reflections.

Bailey, Michael, Anton Strezhnev, and Erik Voeten. 2017. Estimating dynamic state preferences from United Nations voting data. Journal of Conflict Resolution 61 (2): 430-56.

Barnett, Michael, and Martha Finnemore. 1999. The politics, power, and pathologies of international organizations. International organization 53(4): 699-732.

Bearce, David H., and Stacy Bondanella. 2007. “'Intergovernmental Organizations, Socialization, and Member-state Interest Convergence.' International Organization 61:70333.

Beck, Nathaniel, Jonathan N. Katz, and Richard Tucker. 1998. Taking Time Seriously: TimeSeries-Cross-Section Analysis with a Binary Dependent Variable. American Journal of Political Science 42 (4): 1260-1288.

Beigbeder, Y. 1979. The United States' Withdrawal from the International Labor Organization. Industrial Relations 34(2): 223-240.

Blyth, Mark. 2017. Global Trumpism: Why Trump's Victory Was 30 Years in the Making and Why It Won't Stop Here. Foreign Affairs anthology.

von Borzyskowski, Inken. 2019. The Credibility Challenge: How Democracy Aid Influences Election Violence. Cornell University Press.

von Borzyskowski, Inken, and Felicity Vabulas. Forthcoming. Credible Commitments? Explaining IGO Suspensions to Sanction Political Backsliding. International Studies Quarterly.

Boehmer, Charles, Erik Gartzke and Timothy Nordstrom. 2004. Do Intergovernmental Organizations Promote Peace? World Politics 57:1-38.

Carr, E.H. 1964. The Twenty Years Crisis, 1919-1939: An Introduction to the Study of International Relations. New York: Harper and Row, pp. 208-23. 
Carter, David, and Curtis Signorino. 2010. Back to the Future: Modeling Time Dependence in Binary Data. Political Analysis 18 (3): 271-292.

Charnovitz, Steve. 2017. Why the International Exhibitions Bureau Should Choose Minneapolis for Global Expo 2023. GW Law Faculty Publications \& Other Works.

Chayes, A., and A. Chayes. 1991. Compliance without enforcement: state behavior under regulatory treaties. Negotiation Journal 7 (3): 311-330.

Checkel, Jeffrey T. 2005. International Institutions and Socialization in Europe: Introduction and Framework. International Organization 59 (4): 801-26.

Cogan, J. K., Hurd, I., \& Johnstone, I. (Eds.) 2016. The Oxford Handbook of International Organizations. Oxford University Press.

Davis, Christina L. and Meredith Wilf. 2017. Joining the Club? Accession to the GATT/WTO. The Journal of Politics 79:964-978.

Davis, Christina. 2009. “Overlapping Institutions in Trade Policy.” Perspectives on Politics 7(1): 25-31.

Davis, Christina L. 2004. International Institutions and Issue Linkage: Building Support for Agricultural Trade. The American Political Science Review 98:153-169.

Donno, D. 2010. Who is punished? Regional intergovernmental organizations and the enforcement of democratic norms. International Organization, 64(4), 593-625.

Donno, D., Metzger, S. K., \& Russett, B. 2015. Screening Out Risk: IGO s, Member State Selection, and Interstate Conflict, 1951-2000. International Studies Quarterly, 59(2), 251263.

Downs, G. W., Rocke, D. M., \& Barsoom, P. N. 1996. Is the good news about compliance good news about cooperation? International Organization 50 (3): 379-406.

Farrell, H., \& Newman, A. 2017. BREXIT, voice and loyalty: rethinking electoral politics in an age of interdependence. Review of International Political Economy 24 (2): 232-247.

Fearon, James D. 1997. Signaling Foreign Policy Interests: Tying Hands Versus Sinking Costs. Journal of Conflict Resolution 41 (1): 68-90.

Foa, Stefan. 2016. Its the Globalization, Stupid. Foreign Policy, Dec 62016.

Fukuyama, Francis. 2016. US Against the World? Trump's America and the New Global Order', Financial Times, 11 November 2016. 
Gaubatz, Kurt Taylor. 1996. Democratic States and Commitment in International Relations. International Organization 50 (1):109-39.

Gibney, Mark, Linda Cornett, Reed Wood and Peter Haschke. 2013. Political Terror Scale 19762012. Available at http://www.politicalterrorscale.org/ Accessed 3 July 2013.

Gilpin, Robert. 1983. War and change in world politics. Cambridge University Press.

Gray, Julia. 2013. The company states keep: International economic organizations and investor perceptions. Cambridge University Press.

Gray, Julia. 2018. Life, Death, or Zombie? The Vitality of International Organizations. International Studies Quarterly 62(1): 1-13.

Gray, Julia, Rene Lindstadt and Jonathan B. Slapin. Forthcoming. The Dynamics of Enlargement in International Organizations. International Interactions.

Greig, Michael, Andrew Enterline. 2017. COW National Material Capabilities (NMC) Data Documentation, Version 5.

Gruber, Loyd. 2000. Ruling the world: Power politics and the rise of supranational institutions. Princeton University Press.

Haas, Richard. 2018. Liberal World Order, R.I.P. Project Syndicate, March 21 2018. Available at https://www.project-syndicate.org/commentary/end-of-liberal-world-order-by-richard-n-haass-2018-03?barrier=accesspaylog.

Haass, Richard. 2017. https://twitter.com/richardhaass/status/918471381511229440?lang=en.

Hafner-Burton, E. M., \& Tsutsui, K. 2005. Human rights in a globalizing world: The paradox of empty promises. American journal of sociology, 110(5), 1373-1411.

Haftel, Yoram and Alexander Thompson. 2018. When do states renegotiate investment agreements? The impact of arbitration. The Review of International Organizations, 13(1), 2548.

Haftel, Yoram and Alexander Thompson. 2006. The independence of international organizations: concept and applications. Journal of Conflict Resolution 50(2): 253-275.

Haftendorn, Helga, Robert O. Keohane, and Celeste A. Wallander. 1999. Imperfect Unions: Security Institutions Over Time and Space. New York: Oxford University Press.

Hawkins, Kirk, and Cristóbal Rovira Kaltwasser. 2017. The Ideational Approach to Populism. Latin America American Research Review 52(4): 513-528. 
Helfer, L.R. 2006. Not Fully Committed-Reservations, Risk, and Treaty Design. Yale Journal of International Law 31: 367.

Helfer, L. R. 2005. Exiting treaties. Va. L. Rev. 91: 1579.

Hill, J. A. 1982. European Economic Community: The Right of Member State Withdrawal, The. Ga. J. Int'l \& Comp. L. 12: 335.

Hirschman, A. O. 1970. Exit, voice, and loyalty: Responses to decline in firms, organizations, and states. Harvard University Press.

Hobolt, Sara, and Catherine de Vries. 2016. Public Support for European Integration. Annual Review of Political Science 19. Annual Reviews: 413-32.

Holsti, O. R. 1992. Public opinion and foreign policy: Challenges to the Almond-Lippmann consensus. International studies quarterly, 36(4), 439-466.

Houle, Christian, and Paul Kenny. 2018. The Political and Economic Consequences of Populist Rule. Government and Opposition.

Huber, Roland, and Christian Schimpf. 2016. A drunken guest in Europe? The influence of populist radical right parties on democratic quality. Zeitschrift für Vergleichende Politikwissenschaft 10:103-129.

Huber, Roland, and Saskia Ruth. 2017. Mind the Gap! Populism, Participation and Representation in Europe. Swiss Political Science Review 23(4): 462-484.

Hyde, S. D., \& Marinov, N. 2011. Codebook for National Elections Across Democracy and Autocracy (NELDA). New Haven, CT: Yale University.

Iacus, S., G. King, and G. Porro. 2012. Causal Inference Without Balance Checking: Coarsened Exact Matching. Political Analysis 20(1): 1-24.

Ikenberry, G. J. 2000. After victory: institutions, strategic restraint, and the rebuilding of order after major wars. Princeton: Princeton University Press.

Ikenberry, John. 2018. The end of liberal international order? International Affairs 94 (1).

Imber, M. F. 1989. The USA, ILO, UNESCO and IAEA: Politicization and withdrawal in the specialized agencies. Springer.

Johnson, Tana. 2014. Organizational Progeny: Why Governments are Losing Control over the Proliferating Structures of Global Governance. Oxford, UK: Oxford University Press.

Jones, Erik. 2018. Towards a Theory of Disintegration. Journal of European Public Policy 25 (3). Routledge: 440-51. doi:10.1080/13501763.2017.1411381. 
Jupille, Joe, Walter Mattli and Duncan Snidal. 2013. Institutional Choice and Global Commerce. Oxford: Oxford University Press.

Kagan, Robert. 2017. The twilight of the liberal world order. Brookings Institution. https://www.brookings.edu/research/the-twilight-of-the-liberal-world-order/

Kaoutzanis, Christodoulos, Paul Poast and Johannes Urpelainen. 2016. Not Letting 'Bad Apples' Spoil the Bunch: Democratization and Strict International Organization Accession Rules. Review of International Organization 11:399-418.

Karreth, Johannes, and Jaroslav Tir. 2013. International institutions and civil war prevention. Journal of Politics 75(1): 96-109.

Kelley, J. 2004. International actors on the domestic scene: Membership conditionality and socialization by international institutions. International organization, 58(3), 425-457.

Kelley, J., \& Kolev, K. 2010. Election quality and international observation 1975-2004: Two new datasets.

Keohane, Robert. 1984. After hegemony: Cooperation and discord in the world political economy. Princeton University Press.

Kertzer, Joshua D., \& Ryan Brutger. 2016. Decomposing audience costs: Bringing the audience back into audience cost theory. American Journal of Political Science 60(1): 234-249.

King, G., \& Zeng, L. 2001. Logistic regression in rare events data. Political analysis 9 (2): 137 163.

Koremenos, B., Lipson, C., \& Snidal, D. 2001. The rational design of international institutions. International organization 55(4): 761-799.

Koremenos, B., \& Nau, A. 2010. Exit, no exit. Duke J. Comp. \& Int'l L. 21: 81.

Koremenos, B. 2016. The continent of international law: explaining agreement design. Cambridge University Press.

Kucik, Jeffrey, and Eric Reinhardt. 2008. Does Flexibility Promote Cooperation? An Application to the Global Trade Regime. International Organization 62 (3): 477-505.

Kuo, Jason, and Megumi Naoi. 2015. Individual Attitudes. In The Oxford Handbook of the Political Economy of International Trade, edited by Lisa Martin. Oxford: Oxford

Lall, Ranjit. 2017. Beyond Institutional Design: Explaining the Performance of International Organizations. International Organization 71: 245-280. 
Leeds, Brett Ashley, and Burcu Savun. 2007. Terminating alliances: Why do states abrogate agreements? The Journal of Politics 69(4): 1118-1132.

Leeds, Brett Ashley. 1999. Domestic Political Institutions, Credible Commitments, and International Cooperation. American Journal of Political Science 43 (4): 979-1002.

Lipson, Charles. 2003. Reliable Partners: How Democracies Have Made a Separate Peace. Princeton: Princeton University Press.

Mansfield, Edward and Jon Pevehouse. 2006. Democratization and International Organizations. International Organization 60:137-167.

Maoz, Z., P. Johnson, J. Kaplan, F. Ogunkoya, and A. Shreve 2018. The Dyadic Militarized Interstate Disputes (MIDs) Dataset Version 3.0: Logic, Characteristics, and Comparisons to Alternative Datasets. Journal of Conflict Resolution.

Marshall, M.G., K. Jaggers and T. Gurr. 2010. Polity IV Project: Characteristics and Transitions, 1800-2009. Dataset Users’ Manual. Center for Systemic Peace.

Marshall, M. and D. Marshall. 2017. Coup d'état events 1946-2016. Center for systematic peace.

Martin, Lisa L. 2000. Democratic Commitments: Legislatures and International Cooperation. Princeton: Princeton University Press.

McCall Smith, J. 2000. The politics of dispute settlement design: Explaining legalism in regional trade pacts. International Organization 137-180.

McGillivray, Fiona, and Alastair Smith. 2000. Trust and Cooperation Through Agent-Specific Punishments. International Organization 54 (4): 809-24.

Mearsheimer, J. J. 1994. The false promise of international institutions. International security, 19(3), 5-49.

Milner, H. V., \& Tingley, D. H. 2011. Who supports global economic engagement? The sources of preferences in American foreign economic policy. International Organization 65(1): 3768.

Morgan, T. Clifton, and Sally Howard Campbell. 1991. Domestic Structure, Decisional Constraints, and War: So Why Kant Democracies Fight? Journal of Conflict Resolution 35 (2): 187-211.

Olson, Mancur. 1965. The Logic of Collective Action: Public Goods and the Theory of Groups. Cambridge, MA: Harvard University Press.

Orbell, J. M., Schwartz-Shea, P., \& Simmons, R. T. (1984). Do cooperators exit more readily than defectors? American Political Science Review 78(1): 147-162. 
Organski, A.F.K. 1964. World Politics. New York, Alfred A. Knopf.

Pacheco, Julianna. 2012. The Social Contagion Model: Exploring the Role of Public Opinion on the Diffusion of Antismoking Legislation across the American States. The Journal of Politics 74 (1). Cambridge University Press New York, USA: 187-202.

Pelc, Krzysztof J. 2009. Seeking Escape: The Use of Escape Clauses in International Trade Agreements. International Studies Quarterly 53 (2): 349-68.

Penney, E. K. 2002. Is That Legal?: The United States' Unilateral Withdrawal from the AntiBallistic Missile Treaty. Cath. UL Rev. 51: 1287-1393.

Pevehouse, J. 2002. With a little help from my friends? Regional organizations and the consolidation of democracy. American Journal of Political Science 611-626.

Pevehouse, J., and I. von Borzyskowski. 2016. International Organizations in World Politics. In The Oxford Handbook of International Organizations, edited by Jacob Katz Cogan, Ian Hurd and Ian Johnstone, 3-32.

Pevehouse, J., Nordstrom, T., \& Warnke, K. 2004. The Correlates of War 2 international governmental organizations data version 2.0. Conflict Management and Peace Science, 21(2), 101-119.

Pevehouse, J., T. Nordstrom, R. McManus, A. Jamison. 2019. Tracking Organizations in the World: The Correlates of War IGO Data, Version 3.0. Working paper.

Putnam, R. 1988. Diplomacy and domestic politics: the logic of two-level games. International organization 42(3): 427-460.

Rosendorff, P. and H. Milner. 2001. The Optimal Design of International Trade Institutions: Uncertainty and Escape. International Organization 55(4): 829-57.

Schneider, Christina. 2017. Political Economy of Regional Integration. Annual Review of Political Science 20 (1). Annual Reviews.

Schermers, H. G., \& Blokker, N. M. 2011. International institutional law: unity within diversity. Martinus Nijhoff Publishers.

Shukla, Srijan. 2018. International Relations on the Rise of Nationalism: Institutions and Global Governance. McGill Journal of Political Studies.

https://mjps.ssmu.ca/2018/02/09/international-relations-on-the-rise-of-nationalisminstitutions-and-global-governance/

Simmons, B. A. 2000. International law and state behavior: Commitment and compliance in international monetary affairs. American Political Science Review 94(04): 819-835. 
Simmons, B. A., \& Danner, A. 2010. Credible commitments and the international criminal court. International Organization 64(2): 225-256.

Singer, J. David, Stuart Bremer, and John Stuckey. 1972. Capability Distribution, Uncertainty, and Major Power War, 1820-1965. In Bruce Russett (ed) Peace, War, and Numbers, Beverly Hills: Sage, 19-48.

Slapin, J. 2009. Exit, voice, and cooperation: Bargaining power in international organizations and federal systems. Journal of Theoretical Politics 21(2), 187-211.

Smith, Alastair. 1995. Alliance Formation and War. International Studies Quarterly 39 (4): 40525.

Smith, Alastair. 1998. Extended Deterrence and Alliance Formation. International Interactions 24 (4): 315-43.

Snidal, D. 1985. The limits of hegemonic stability theory. International organization, 39(4), 579614.

Snyder, J. 2019. The Broken Bargain. Foreign Affairs, March-April, 54-60.

State Dept. 1997. US Participation in Special Purpose International Organizations. US GAO, NSIAD 97-35.

Stone, Randy. 2011. Controlling institutions: International organizations and the global economy. Cambridge University Press.

Vabulas, F., \& Snidal, D. 2013. Organization without delegation: Informal intergovernmental organizations (IIGOs) and the spectrum of intergovernmental arrangements. The Review of International Organizations 8(2): 193-220.

Von Stein, Jana. 2005. Do treaties constrain or screen? Selection bias and treaty compliance. American Political Science Review, 99(4), 611-622.

Wagner, R. H. 2000. Bargaining and war. American Journal of Political Science, 469-484.

Walter, B. F. 2009. Bargaining failures and civil war. Annual Review of Political Science, 12, 243-261.

Walter, Stefanie. 2018. The Mass Politics of International Disintegration. Paper prepared for presentation at the International Relations research seminar, Harvard University, 8 March 2018. 
Figure 1A: IGO Withdrawals across Time, 1945-2014

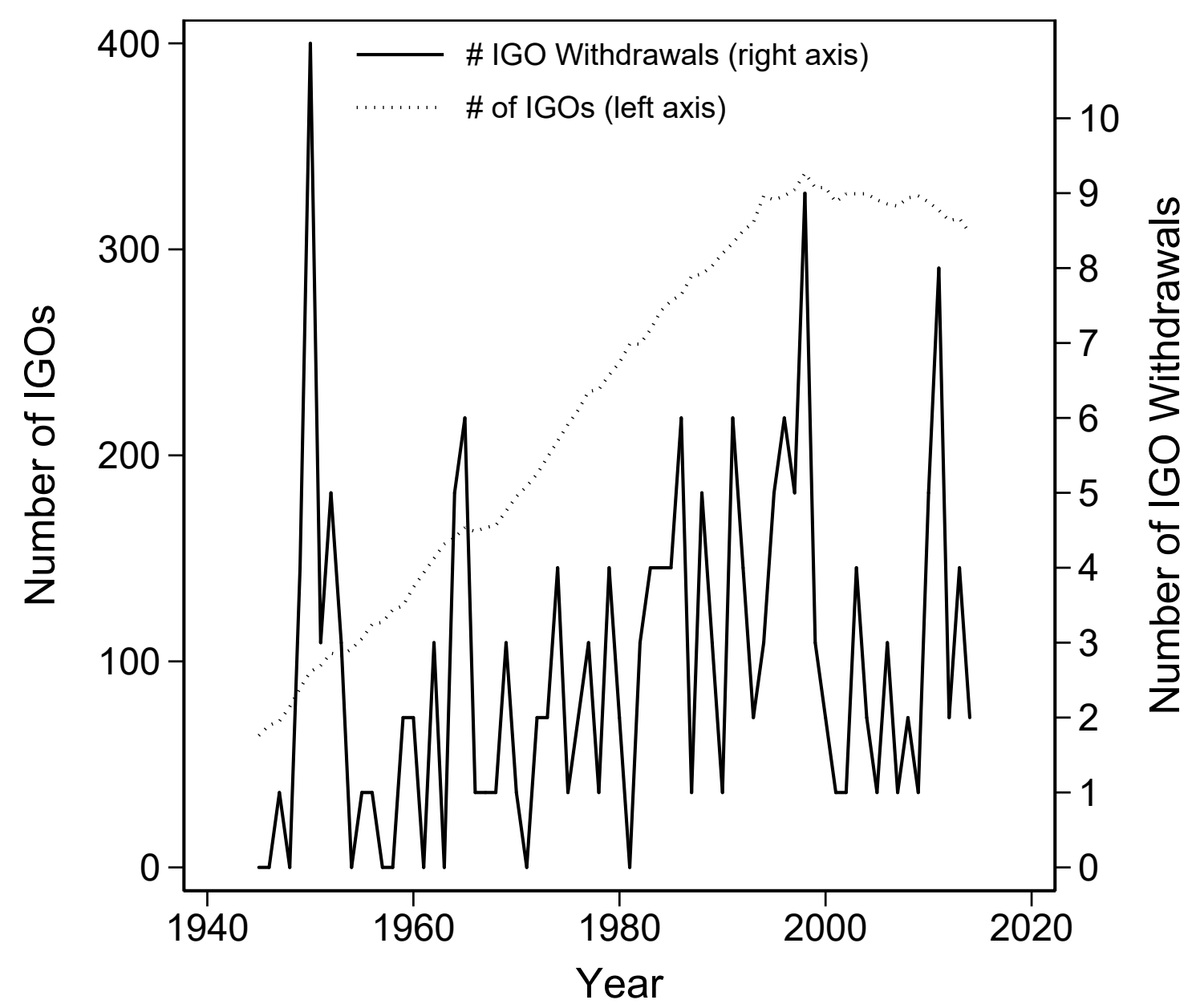


Figure 1B: Number of Withdrawals over Number of IGOs, 1945-2014

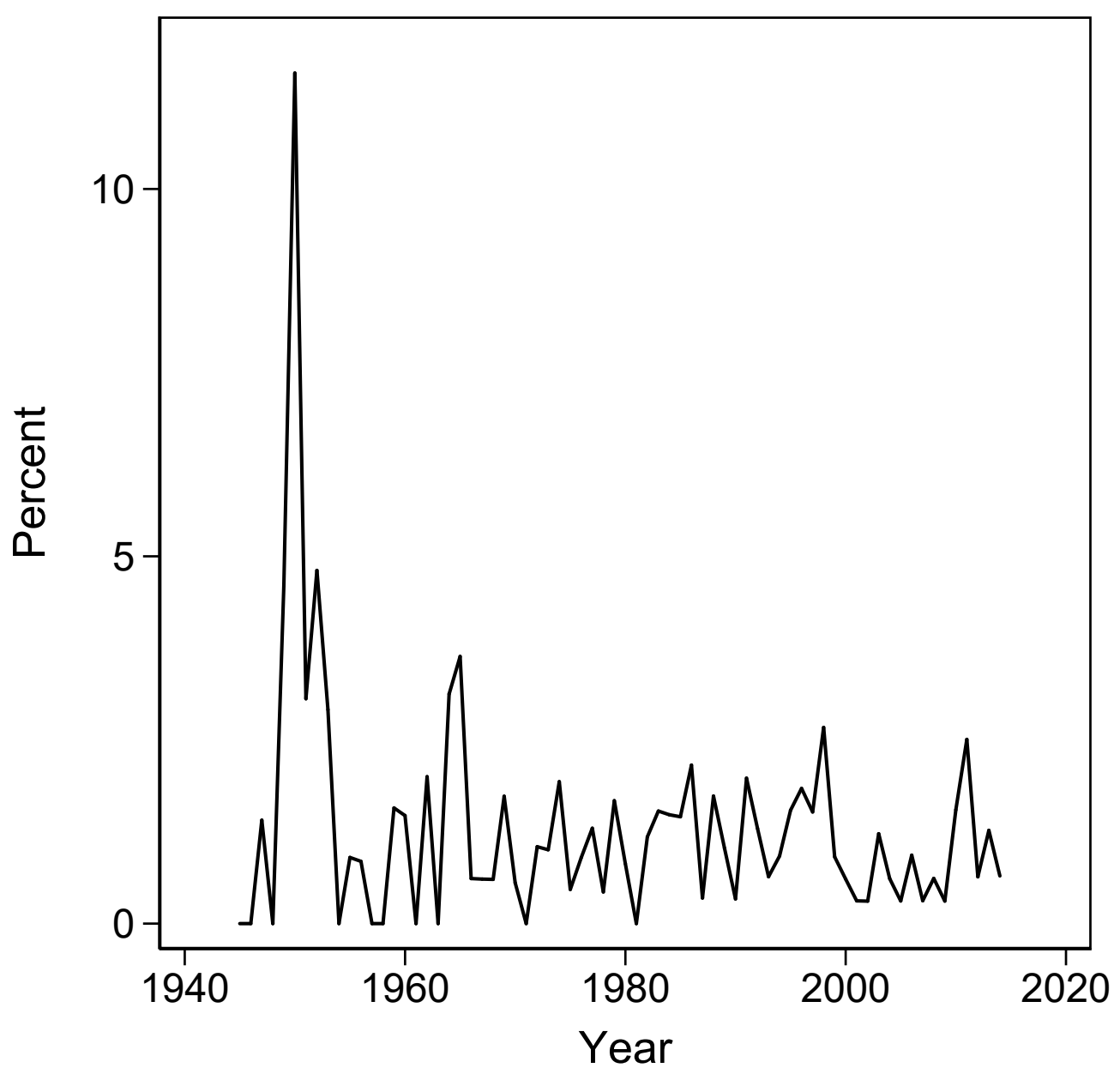


Figure 2: Top IGO Withdrawals across States, 1945-2014

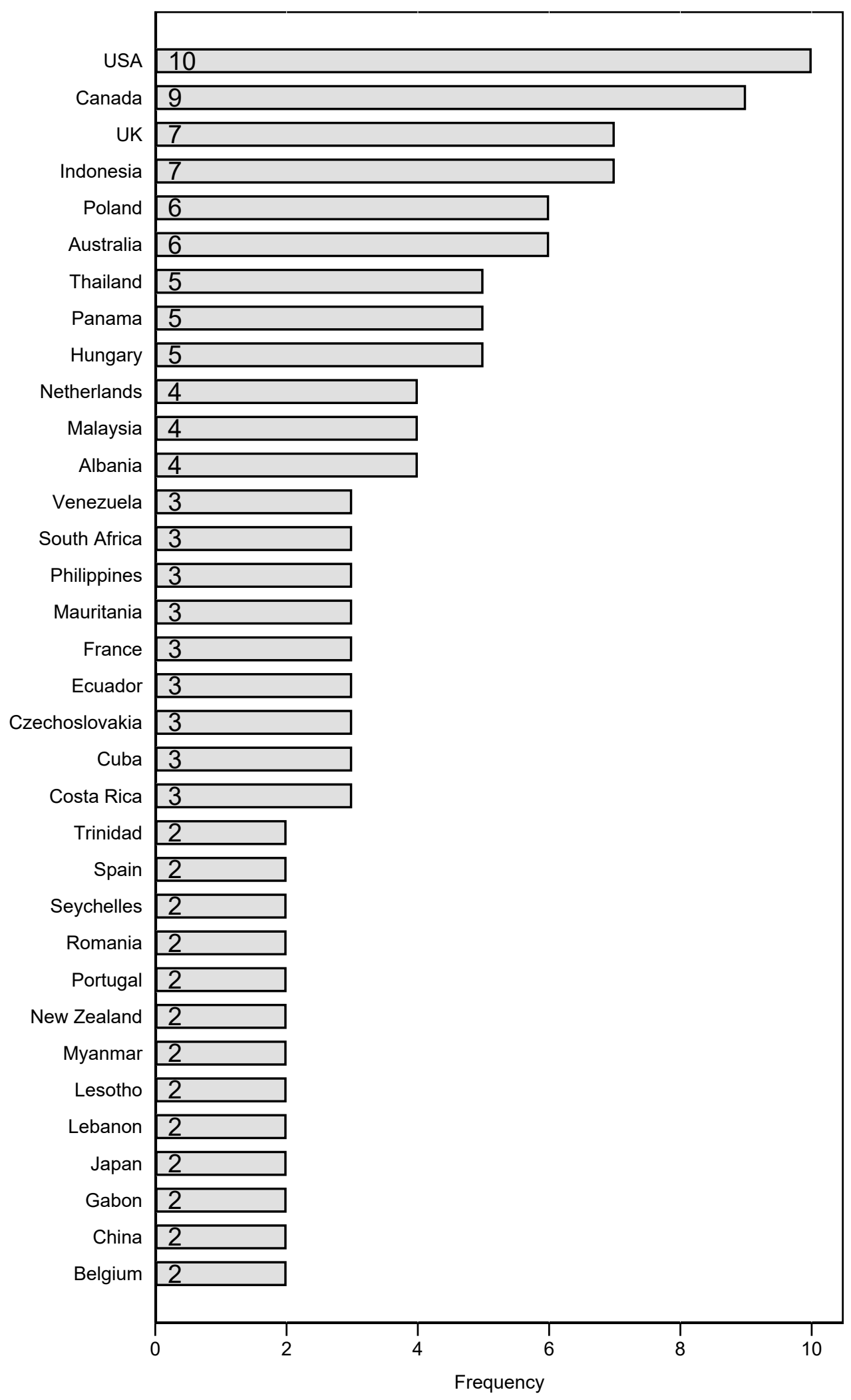


Figure 3: Top IGO Withdrawals across Organizations, 1945-2014

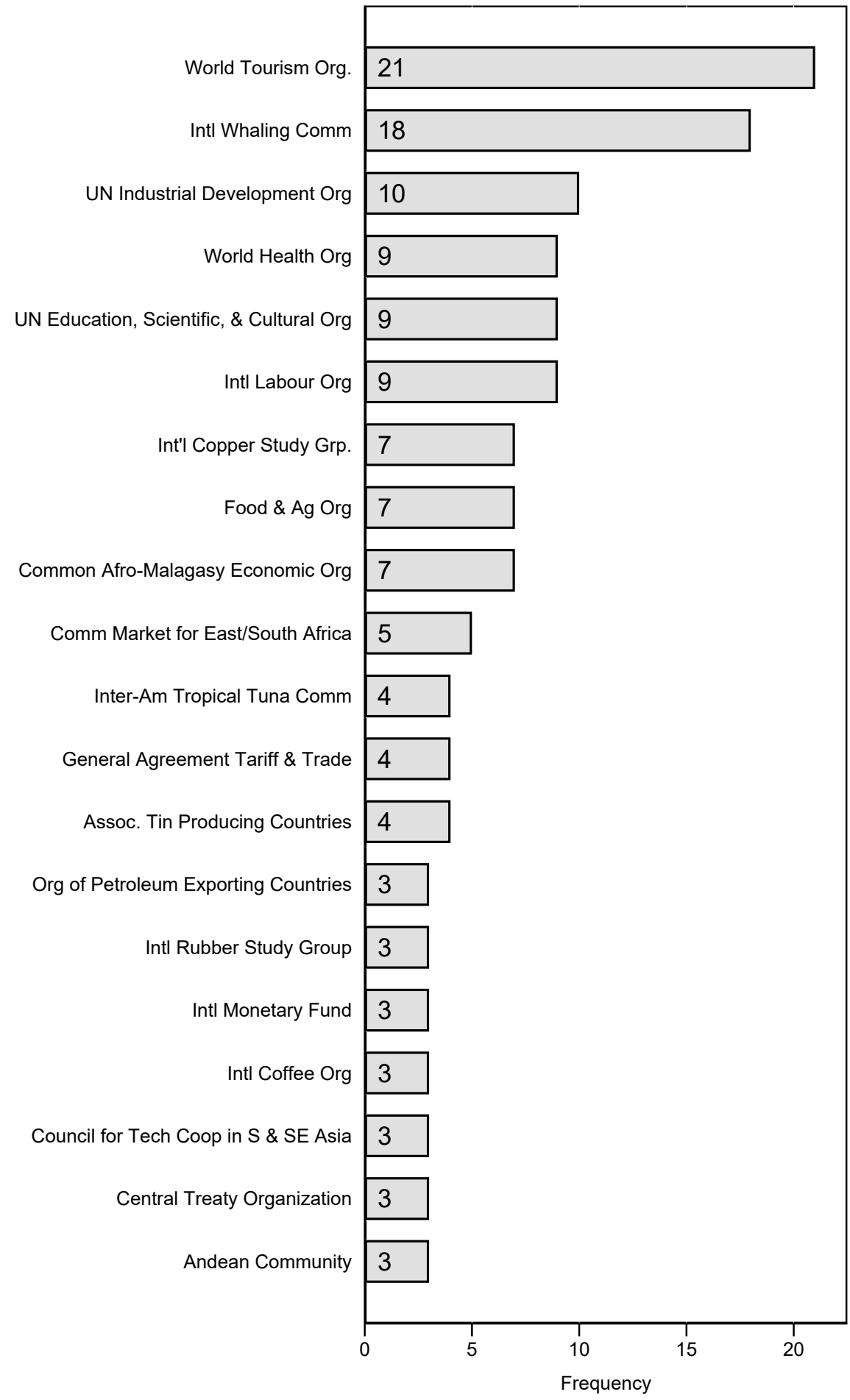


Figure 4: Reason for IGO Withdrawals, 1945-2014

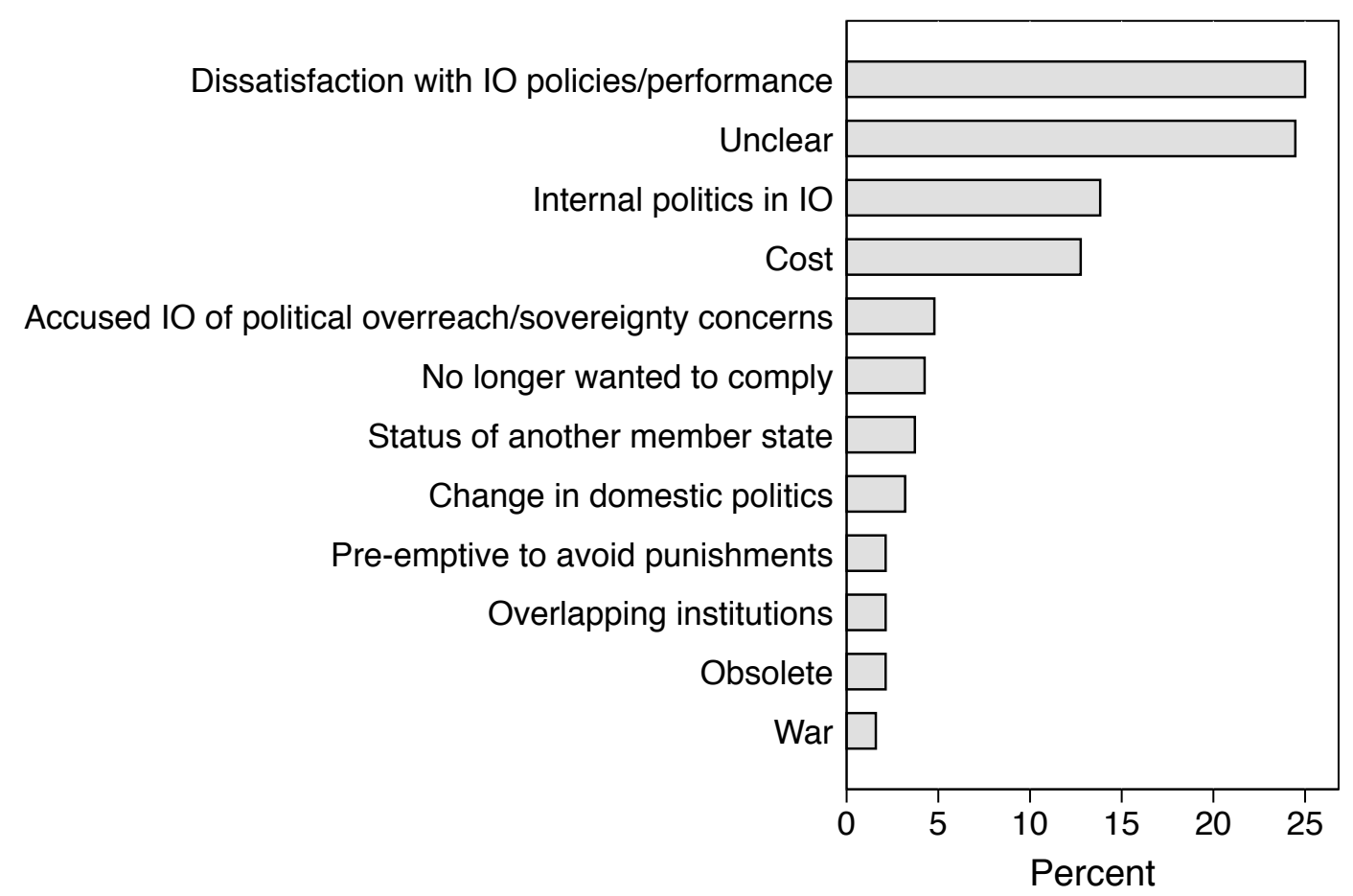


Figure 5: Coefficient Estimates of Alternative Nationalism Measures (Estimated from Column 1 for 1990-2014)

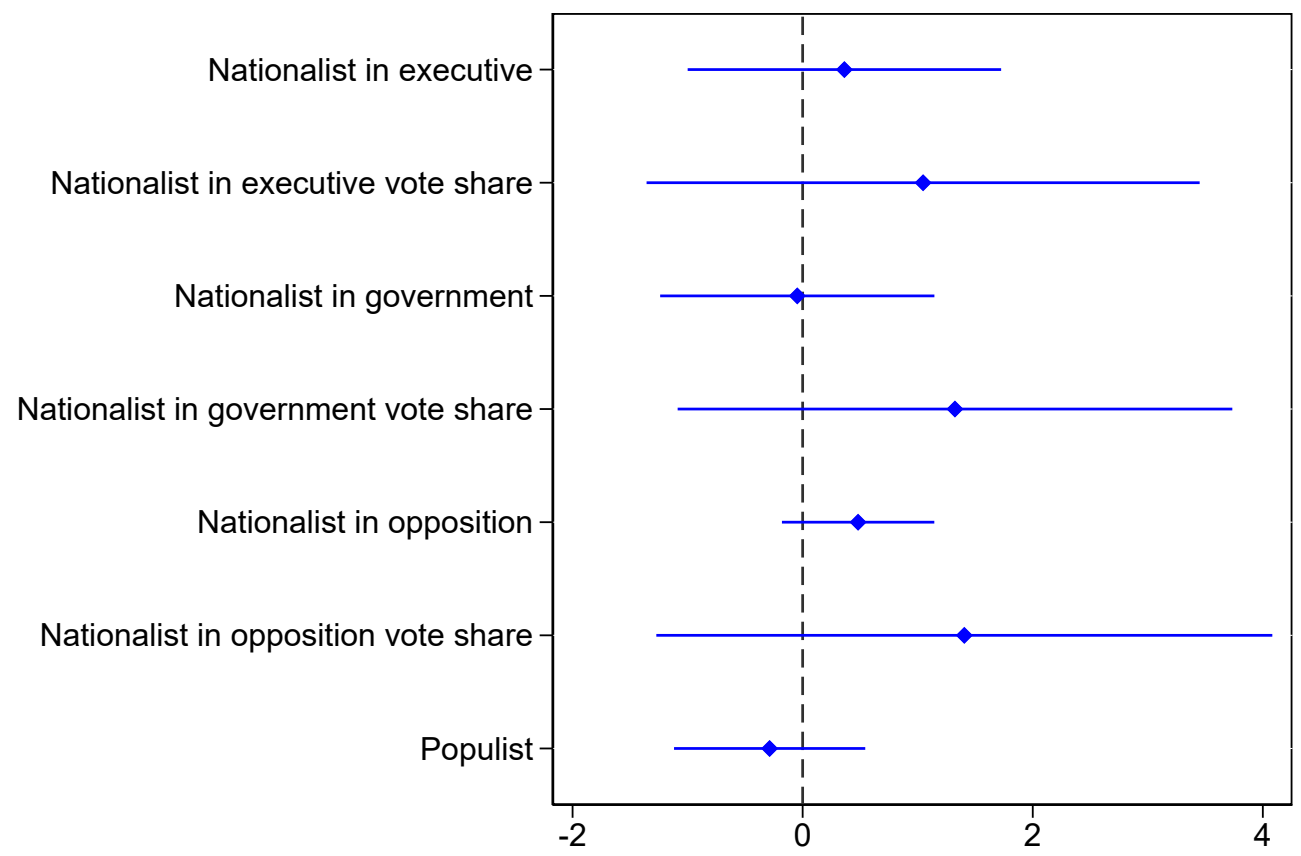


Table 1: Determinants of IGO Withdrawals, 1945-2014

\begin{tabular}{|c|c|c|c|c|}
\hline & $\begin{array}{c}(1) \\
\text { Domestic }\end{array}$ & $\begin{array}{l}(2) \\
\text { IGO }\end{array}$ & $\begin{array}{c}(3) \\
\text { Geopolitics }\end{array}$ & $\begin{array}{l}(4) \\
\text { All }\end{array}$ \\
\hline Democracy & $\begin{array}{l}0.056 \\
(0.029)^{*}\end{array}$ & & & $\begin{array}{l}0.060 \\
(0.025)^{* *}\end{array}$ \\
\hline Government orientation change & $\begin{array}{l}0.333 \\
(0.270)\end{array}$ & & & $\begin{array}{l}0.553 \\
(0.301)^{*}\end{array}$ \\
\hline Nationalist & $\begin{array}{l}0.090 \\
(0.467)\end{array}$ & & & $\begin{array}{l}-0.496 \\
(0.619)\end{array}$ \\
\hline IO institutionalization & & $\begin{array}{l}0.035 \\
(0.273)\end{array}$ & & $\begin{array}{l}-0.180 \\
(0.334)\end{array}$ \\
\hline IO average democracy score & & $\begin{array}{l}-0.019 \\
(0.035)\end{array}$ & & $\begin{array}{l}-0.093 \\
(0.039)^{* *}\end{array}$ \\
\hline IO issue area politics & & $\begin{array}{l}-0.063 \\
(0.459)\end{array}$ & & $\begin{array}{l}-0.542 \\
(0.688)\end{array}$ \\
\hline IO issue area economics & & $\begin{array}{l}0.365 \\
(0.416)\end{array}$ & & $\begin{array}{l}0.511 \\
(0.435)\end{array}$ \\
\hline Preference diversion from IO average & & & $\begin{array}{l}0.950 \\
(0.153)^{* * *}\end{array}$ & $\begin{array}{l}1.175 \\
(0.207)^{* * *}\end{array}$ \\
\hline Contagion & & & $\begin{array}{l}3.348 \\
(0.400)^{* * *}\end{array}$ & $\begin{array}{l}3.166 \\
(0.438)^{* * *}\end{array}$ \\
\hline State power change & & & $\begin{array}{l}-0.701 \\
(0.144)^{* * *}\end{array}$ & $\begin{array}{l}-0.911 \\
(0.930)\end{array}$ \\
\hline Membership duration in IO & $\begin{array}{l}0.543 \\
(0.385)\end{array}$ & $\begin{array}{l}-0.074 \\
(0.286)\end{array}$ & $\begin{array}{l}-0.536 \\
(0.323)^{*}\end{array}$ & $\begin{array}{l}0.199 \\
(0.568)\end{array}$ \\
\hline IO size & $\begin{array}{l}-0.223 \\
(0.234)\end{array}$ & $\begin{array}{l}-0.412 \\
(0.218)^{*}\end{array}$ & $\begin{array}{l}-0.606 \\
(0.192)^{* * *}\end{array}$ & $\begin{array}{l}-0.645 \\
(0.317)^{* *}\end{array}$ \\
\hline Observations & 207830 & 338942 & 418898 & 152158 \\
\hline $\mathrm{AIC}$ & 1456.366 & 2625.544 & 2654.137 & 972.498 \\
\hline $\mathrm{BIC}$ & 1548.566 & 2732.880 & 2752.645 & 1131.421 \\
\hline
\end{tabular}

Note: Rare events logit models with robust standard errors clustered on IGO in parentheses ${ }^{*} p<0.10,{ }^{* *} p<0.05,{ }^{* * *} p<0.01$ 